\title{
Endocytosis and Cancer
}

\author{
Ira Mellman ${ }^{1}$ and Yosef Yarden ${ }^{2}$ \\ ${ }^{1}$ Genentech Inc., South San Francisco, California 94080 \\ ${ }^{2}$ Department of Biological Regulation, Weizmann Institute of Science, Rehovot 76100, Israel \\ Correspondence: yosef.yarden@weizmann.ac.il
}

Endocytosis entails selective packaging of cell-surface proteins, such as receptors for cytokines and adhesion components, in cytoplasmic vesicles (endosomes). The series of sorting events that determines the fate of internalized proteins, either degradation in lysosomes or recycling back to the plasma membrane, relies on intrinsic sequence motifs, posttranslational modifications (e.g., phosphorylation and ubiquitination), and transient assemblies of both Rab GTPases and phosphoinositide-binding proteins. This multicomponent process is enhanced and skewed in cancer cells; we review mechanisms enabling both major drivers of cancer, p53 and Ras, to bias recycling of integrins and receptor tyrosine kinases (RTKs). Likewise, cadherins and other junctional proteins of cancer cells are constantly removed from the cell surface, thereby disrupting tissue polarity and instigating motile phenotypes. Mutant forms of RTKs able to evade Cbl-mediated ubiquitination, along with overexpression of the wild-type forms and a variety of defective feedback regulatory loops, are frequently detected in tumors. Finally, we describe pharmacological attempts to harness the peculiar endocytic system of cancer, in favor of effective patient treatment.

$\mathrm{C}$ ancer cells are fundamentally similar to their normal counterparts. Their differences lie in a series of relatively subtle modifications of normal physiological processes that, when combined, can create markedly altered phenotypes and behaviors. It has long been suspected that endocytosis is one such physiological process that is modified in cancer. Not only do cancer cells show alterations in the overall appearance and dynamics of the plasma membrane, but also the common inability of cancer cells to properly regulate the function of several types of receptors, including many RTKs, strongly suggests an inability to internalize, recycle, or degrade these key cancer drivers. In recent years, there has been considerable progress made toward under- standing the breadth and mechanisms of alterations to the endocytic pathway that occur during cancer. Although our knowledge remains incomplete and the pathophysiological contributions of these alterations may not be wholly understood, this review considers just how profoundly the pathways of endocytosis can be modified in cancer and what this reveals about disease mechanisms and normal processes.

\section{Organization of the Endocytic Pathway}

Although the basic features of the endocytic pathway in animal cells were established more than two decades ago (Mellman 1996a), subsequent years have witnessed the accumulation of

Editors: Sandra L. Schmid, Alexander Sorkin, and Marino Zerial

Additional Perspectives on Endocytosis available at www.cshperspectives.org

Copyright (C) 2013 Cold Spring Harbor Laboratory Press; all rights reserved; doi: 10.1101/cshperspect.a016949

Cite this article as Cold Spring Harb Perspect Biol 2013;5:a016949 
a vast array of new information that has not only filled out mechanistic details but has also provided some important new concepts regarding the role of endosomes and lysosomes in regulating cell physiology ( for a recent review, see Huotari and Helenius 2011). Here, we provide only a brief introduction to endocytosis by way of context for a consideration of its role in cancer.

By definition, endocytosis is initiated by the invagination of a segment of plasma membrane. Typically, this involves the concerted action of the coat protein clathrin together with its associated subunits and regulatory proteins (Brodsky 2012), yielding a "clathrin-coated vesicle" (CCV) of $\sim 0.2 \mu \mathrm{m}$ in diameter. CCVs are important in cancer because they have the ability to select receptors intended for entry, the first step in the process of receptor down-regulation. CCVs perform this task by decoding specific recognition sequences found on the cytoplasmic domains of many receptors or interacting with posttranslational modifications such as ubiquitination, acetylation (Goh et al. 2010), or lysine methylation of the internalizing receptor (Hsu et al. 2011). Other types of endocytic vesicles can also form notably small vesicles that lack clathrin coats, some of which are derived from plasma membrane "caveolae" that contain defined-lipid microdomains that are involved in a variety of signal transduction events (e.g., GPI-anchored proteins and some G-proteincoupled receptors) (see Mayor et al. 2014). Larger vesicles, called "macropinosomes," can also form in many cell types with macropinocytosis occurring either constitutively in some examples or by induced receptor stimulation or bacterial entry in others; typically, macropinocytosis reflects local activation of Cdc42 (Garrett et al. 2000).

In general, endocytic vesicles fuse with a population of small vesicles and tubules referred to as early endosomes (EEs). These structures are mildly acidic ( $\mathrm{pH}$ 6.0-6.8) and facilitate the dissociation of many ligands from their receptors. The newly freed ligands accumulate in the EE lumen and are transferred to late endosomes and finally to lysosomes for degradation. Receptors show two fates. First, they can be recycled back to the plasma membrane by either return- ing directly from EEs or passing through a population of pericentriolar organelles termed "recycling endosomes." The kinetics of recycling vary between these two routes, with the direct return being manifold faster (1-2 min vs 15$20 \mathrm{~min})$. One result of passage through recycling endosomes is the formation of a substantial intracellular pool of recycling receptors.

Alternatively, especially in the case of activated RTKs, recycling can be rendered relatively inefficient with the receptors (with or without bound ligand) being transferred to late endosomes and lysosomes for degradation ("downregulation"). This pathway is triggered by receptor ubiquitination, with ubiquitin monomers or oligomers being recognized by a second cytosolic coat termed the endosomal sorting complex required for sorting (ESCRT) (Henne et al. 2013; Piper et al. 2014). First described in yeast (Katzmann et al. 2001), four such subcomplexes exist (ESCRT0-3) with proteins Hrs, STAM (ESCRT0), and Tsg101 (ESCRT1) responsible for the ubiquitin recognition event. In concert with ESCRT2-3, already beginning at the level of EEs, these complexes help to drive the invagination of small segments of endosomal membrane $(\sim 0.1 \mu \mathrm{m})$ to form the "intralumenal vesicles" (ILVs) characteristic of late endosomes and lysosomes, therefore often called "multivesicular bodies" (MVBs). RTKs selected for entry into forming ILVs are therefore sequestered, prevented from recycling, and degraded as the proteolytic environment within the endosome develops, whereas EEs mature to late endosomes and lysosomes. The ESCRTs, therefore, act as agents of cargo selection and vesicle formation. At least under some conditions, Tsg101 may act as a tumor suppressor and is dysregulated in cancer (Li and Cohen 1996), although redundancy within the ESCRT system has prevented a clear assessment of its role (Raiborg and Stenmark 2009). As discussed below, c-Cbl is the E3 ligase likely responsible for adding the ubiquitins that are required for sequestration of internalized RTKs in MVBs (Levkowitz et al. 1998).

Endocytic organelles, therefore, are functionally organized to permit the sorting of recycling receptors from receptors and ligands destined for degradation. Most of this sorting 
occurs at the level of EEs. It must be emphasized, however, that the entire system is incredibly dynamic, handling a bidirectional flux of membrane components that dwarf each hour the aggregate surface area of the organelles involved. Therefore, it is most useful to think of the endocytic pathway as a series of functionally and biochemically defined organelles that are intimately interconnected, with a continuous but highly regulated maturation process mediated by the selective insertion and removal of individual membrane components (Huotari and Helenius 2011).

\section{Overview of Endocytic Organelle Signaling Functions}

Although it is commonly assumed that most signaling events occur at the plasma membrane, there is increasing reason to believe that endocytic organelles may have important roles in signal transduction, beyond simply supplying a mechanism to down-regulate RTKs. It is clear that various lipid kinases together with Ras-related Rab family GTPases have key roles in regulating the formation and maturation of endocytic organelles. Beyond generating signals to regulate their own behavior, however, endocytic organelles may also serve as signaling platforms for the mitogen-activated protein kinase (MAPK) pathway and possibly transforming growth factor $\beta$ (TGF- $\beta$ ) receptor signaling (see below). In addition, recent evidence has implicated lysosomes - typically only thought of as end-stage degradative organelles-as key players in signaling via mTOR. Cellular ATP and amino acid levels regulate the V-ATPase-mediated assembly of the "Ragulator" complex, comprising the RAG family GTPases together with RHEB GTPase to recruit mTORC1, thereby activating an mTOR kinase (Zoncu et al. 2011). Similarly, the fusion of autophagosomes with lysosomes is also regulated at least in part by mTOR activity, further emphasizing a broader function for lysosomes in cellular homeostasis relevant to generating or suppressing the cellular oncogenic phenotype (for reviews, see Laplante and Sabatini 2012; Jewell et al. 2013). Inhibiting mTORC1 function has proved to be an effective therapy in hormone-dependent breast cancer (Baselga et al. 2012a), emphasizing a likely relationship between endocytic organelle function and cancer.

We now turn to a consideration of how the endocytic pathway is altered or otherwise coopted in cancer cells and how these alterations contribute to pathophysiology. The main themes are vesicular trafficking-mediated formation of specialized cell-surface extensions as well as cellular processes leading to acquisition of rapid proliferation or invasive growth (Fig. 1)

\section{BOTH MAJOR DRIVERS OF HUMAN CANCER, p53 AND RAS, HARNESS ENDOCYTOSIS}

Mutant Forms of p53

Wild-type p53 acts as a transcription factor that induces cell-cycle arrest, apoptosis, or senescence after stress (Oren and Rotter 2010). In $\sim 50 \%$ of human tumors, p53 is either lost or inactivated by point mutations. Mutant forms of p53 may act in cancer as trans-dominant inhibitors of p53 (Blagosklonny 2000), and studies performed by Vousden and Norman identified an endocytosis-related gain of function of p53 mutant that is independent of loss of wild-type p53 (Muller et al. 2010). Accordingly, certain mutants drive random migration of cancer cells by accelerating recycling of $\beta 1$-integrin. This function may at least in part depend on the Rab-coupling protein (RCP), an effector and binding partner of the Rab11 family of small GTPases dedicated to the control of vesicle recycling (Mills et al. 2009). In addition to integrins, two RTKs, EGFR and c-MET, are influenced by mutant forms of p53; enhanced recycling of these receptors signals downstream from the proinvasive kinase Akt, which results in disordered lamellipodia, cell scattering, reduced directional cell migration, and increased invasiveness (Muller et al. 2012). Interestingly, by recruiting RCP and accelerating receptor recycling, mutants of p53 overcome the metastasisinhibitory function of p63, a kin of p53 (Fig. 2).

Coincident with the discovery of a link between mutant p53 and RCP, a survey of recurrent 


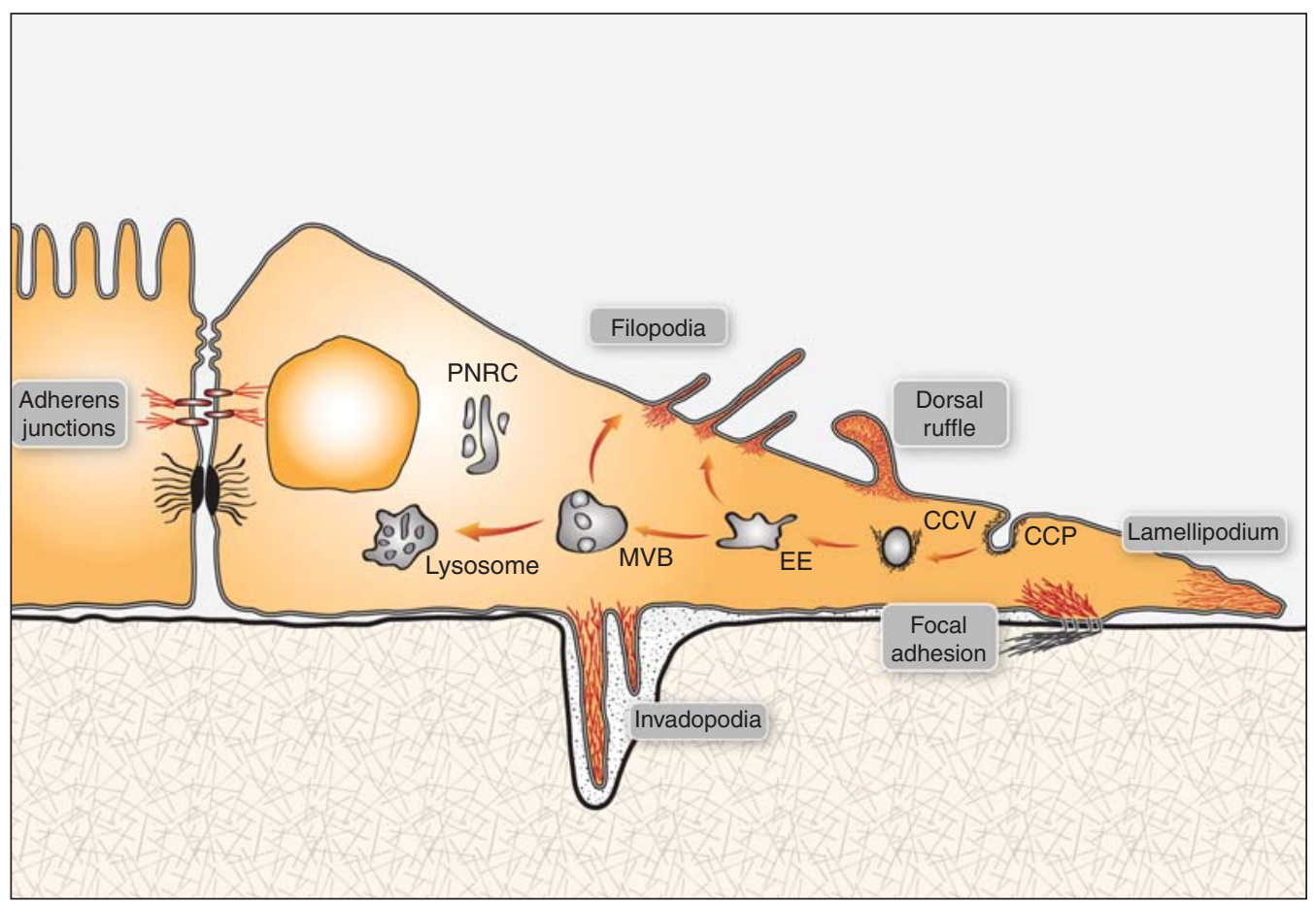

Figure 1. Cell-surface structures regulated in tumors by vesicular trafficking. A schematic view of an epithelial cell, which is in close contact with both a highly polarized neighboring cell, via adherens junctions, and the underlying extracellular matrix (via focal adhesions). Several actin-filled projections of the plasma membrane are presented (e.g., a lamellipodium and several filopodia). In addition, ventrally located invadopodia are shown as actin-filled fingers that perforate the underlying extracellular matrix. Turnover of all presented surface structures is regulated by vesicular trafficking, which is outlined as a route starting at the clathrin-coated pit (CCP), leading to EEs, late endosomes, or multivesicular bodies (MVBs), and eventually reaches lysosomes. Both adhesion molecules, such as integrins and signaling receptors (e.g., EGFR), are transported to lysosomes through this pathway, but an alternative route recycles receptors back to the cell surface. In the case of integrins, this latter route involves the perinuclear recycling compartment (PNRC). Note that Figures 2-5 highlight portions of the general view shown in this scheme.

genomic amplicons and their impact on patient survival identified RCP as a human breast-cancer-promoting gene (Zhang et al. 2009). The corresponding gene localizes to a region of chromosome $8(8 \mathrm{p} 11-12)$ that is frequently amplified in breast cancer. Importantly, amplification of $8 \mathrm{p} 11-12$ has been observed in $10 \%-25 \%$ of breast tumor cases and is correlated with poor patient survival (Letessier et al. 2006). In vitro studies support the ability of an overexpressed $\mathrm{RCP}$ to confer aggressiveness to mammary tumor, and have also found that this associates with activation of the Ras-Erk MAPK pathway. As described below, the plot implicating RCP in ma- lignant transformation has thickened even further by the finding that RCP partners, such as Rab25, are overexpressed in breast and ovarian tumors (Cheng et al. 2004), and the RCP-Rab25 complex can promote invasive migration in three dimensions (Caswell et al. 2007). Thus, multiple mechanisms may be used by cancer cells to achieve increased receptor recycling, thereby enhancing invasiveness.

\section{Mutant Forms of Ras}

Like $\mathrm{p} 53$, the three Ras family members H-Ras, $\mathrm{K}-\mathrm{Ras}$, and $\mathrm{N}$-Ras acquire oncogenic properties 


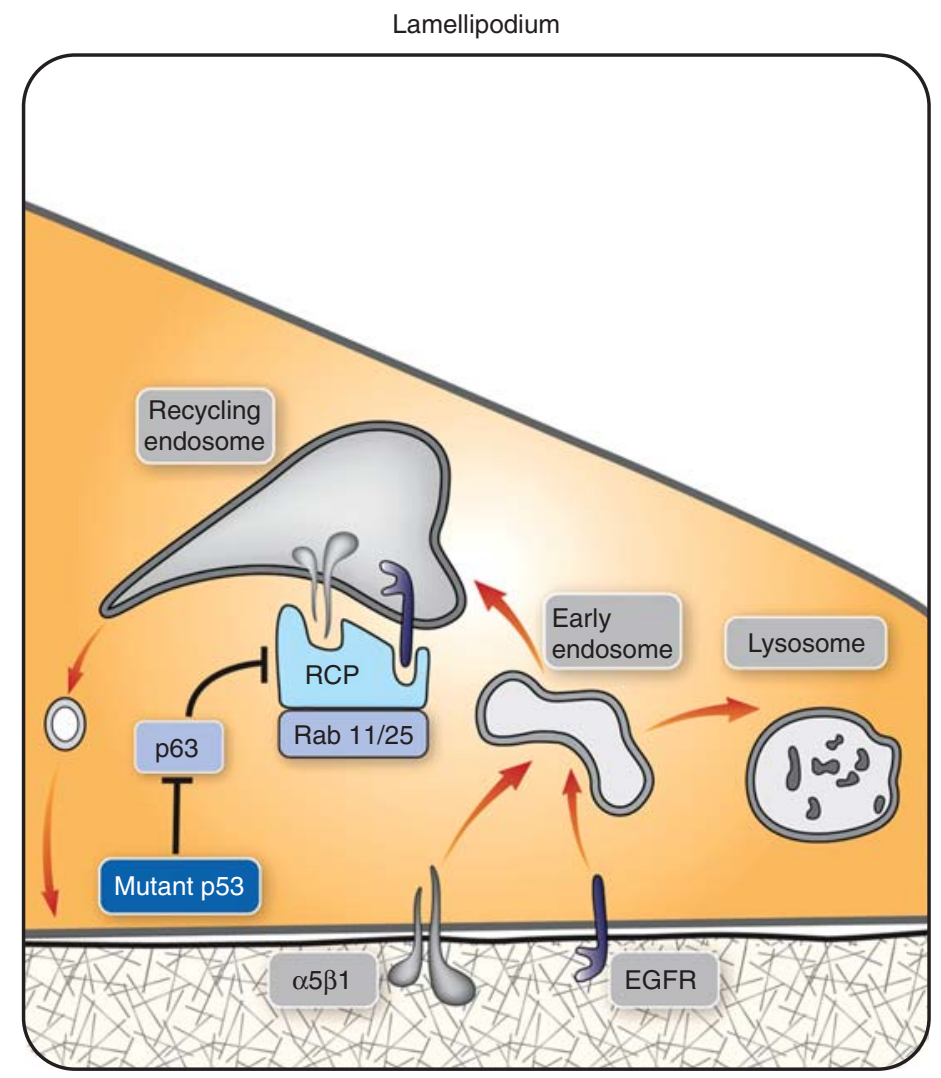

Figure 2. Involvement of mutant p53 in lamellipodium dynamics and cell migration. To safeguard sustained forward movement of the leading edge, integrin and RTKs constantly internalize and directionally recycle by means of vesicular trafficking. A critical player is the RCP, a Rab11 effector, that physically binds with both RTKs and integrins such as the fibronectin receptor $\alpha 5 \beta 1$. This enables cotrafficking of adhesion and signaling molecules to the forefront of the leading edge. Importantly, the endosomal protein RCP, like its partner, Rab25, is overexpressed in some tumors and indirectly down-regulated by $\mathrm{p} 63$. The latter transcription factor is a member of a tumor suppressor family that includes also p73 and the wild-type form of p53. Notably, oncogenic mutant forms of $\mathrm{p} 53$, such as $\mathrm{R} 175 \mathrm{H}$ and $\mathrm{R} 273 \mathrm{H}$, transcriptionally repress $\mathrm{p} 63$. Thus, in cancer cells expressing p53 mutants, both RTKs and certain integrins evade degradation in lysosomes, thereby enhancing cell migration and downstream signaling, primarily to the Akt pathway.

by single missense mutations, usually at codon 12 or codon 61 (Pylayeva-Gupta et al. 2011). Whereas several lines of evidence indicate that mutants of Ras exploit the endocytic machinery, the functional significance of these events remains poorly understood. For example, it was noted early on that microinjection of the H-Ras protein into fibroblasts increased both surface ruffles and fluid phase macropinocytosis within 30-60 minutes (Bar-Sagi and Feramisco 1986). However, although it is clear that Ras can remodel the actin cytoskeleton to promote ruffling, the interaction with vesicle-forming machineries, along with the contribution of macropinocytosis to the transformed phenotype, are less understood. Another isoform of Ras, K-Ras, transcriptionally elevates caveolin-1 through a mechanism involving Akt, and this enhances tumor cell migration (Basu Roy et al. 2012).

Along with macropinocytosis, Ras activation strongly induces clathrin-dependent endocytosis at least in part by regulating the monomeric GTPase Rab5. Rab5 is known as a regulator of fusion between EEs. Key players 
in these events are the Ras-interaction/interference (Rin) proteins, Ras effectors that connect signaling to the control of receptor endocytosis and actin remodeling (Tall et al. 2001). Via its Ras association (RA) domain, Rin1 competes with binding of another Ras effector, Raf, whereas the Vps9 domain is necessary for binding to Rab5 and for GDP/GTP exchange activity. In addition, Rin1 directly binds active EGFRs via its $\mathrm{SH} 2$ domain and uses its own phosphotyrosines to bind Abl tyrosine kinases that regulate actin remodeling. Thus, Rin1 functions as a hub linking potent proto-oncogenes, such as Raf and $\mathrm{Abl}$, to the endocytic machinery. Because Ras potentiates the Rab5 nucleotide exchange activity of Rin1, this interaction augments Rab5A-dependent endosome fusion and EGFRmediated endocytosis. In contrast, Rin1-Abl signaling stabilizes EGFR and inhibits macropinocytosis (Balaji et al. 2012).

The potential functional significance of Rinl's interaction with Ras, EGFR, and Abl is supported by evidence showing that overexpression of Rin1 suppresses apoptosis in vitro and correlates with poor prognosis of melanoma patients (Fang et al. 2012). A similar prognostic correlation was reported in non-small-cell lung cancer and in gastric tumors (Wang et al. 2012). In colorectal tumors, Rin1 expression correlated not only with poor prognosis but also with venous invasion (Senda et al. 2007). Congruent with growth-factor-driven invasiveness and metastasis, studies performed on lung cancer cell lines suggested that Rin1 regulates cell proliferation through EGFR (Tomshine et al. 2009). These observations suggest that the interactions between Rin1 and Abl are favored in tumors more so than the alternative actions of Rin1 on Rab5 and Raf.

Yet more complexity has been introduced by reports on ubiquitination of Ras and Rho family members and potential relevance to tumorigenesis (de la Vega et al. 2011). The group of Bar-Sagi reported that H-Ras is subject to ubiquitin conjugation (Jura and Bar-Sagi 2006). Interestingly, ubiquitin attachment to $\mathrm{H}$-Ras is mediated by another Rab5 GEF - an E3 ligase and an ubiquitin-binding protein called Rabex5. Ubiquitination stabilizes the association of
H-Ras with endosomes an inhibits its ability to activate Raf (Xu et al. 2010). Moreover, Rin1 is required for Rabex-5-dependent H-Ras ubiquitination, suggesting a feedback mechanism by which H-Ras activates Rin1 and the latter recruits Rabex-5 to ubiquitinate, thereby inactivating $\mathrm{H}$-Ras. A different model was proposed by a study of K-Ras ubiquitination. This modification enhanced, rather than weakened, coupling to downstream effectors such as Erk and PI3K (Sasaki et al. 2011), raising the possibility that endocytosis of K-Ras activates signaling, but internalization of H-Ras inhibits downstream signals. It is worthwhile to note that that earlier observations concluded that $\mathrm{H}$-Ras signaling and K-Ras signaling are differentially dependent on endocytosis (Roy et al. 2002). Moreover, EGFR signaling results in the recruitment of K-Ras to late endosomes and lysosomes, an event that does not occur in the case of H-Ras or N-Ras (Lu et al. 2009).

\section{ONCOGENIC MUTANTS OF GROWTH FACTOR RECEPTORS ARE ENDOCYTOSIS IMPAIRED}

The canonical pathway that clears from the cell-surface-activated forms of RTKs, along with their bound growth factor molecules (Sorkin and von Zastrow 2009), is often avoided by growth factor receptors of cancer cells, either because they carry oncogenic mutations or they are otherwise aberrantly expressed (Mosesson et al. 2008; Parachoniak and Park 2012). Receptor internalization is mediated by clathrin-dependent and -independent, routes (Sigismund et al. 2005), eventually delivering cargoes to EEs. Within endosomes, activated RTKs are either transferred to late endosomes and lysosomes for degradation, or they are recycled, providing sustained signaling (Parachoniak et al. 2011). Multiple factors regulate sorting at the endosome and they include receptor autophosphorylation, ligand affinity and its sensitivity to $\mathrm{pH}$, ubiquitination by $\mathrm{Cbl}$ and other ubiquitin ligases, and several adaptor proteins such as Grb2 and ubiquitin binders. Oncogenic tricks that manipulate RTK sorting are reviewed below by focusing on two subfamilies of RTKs (Fig. 3). 


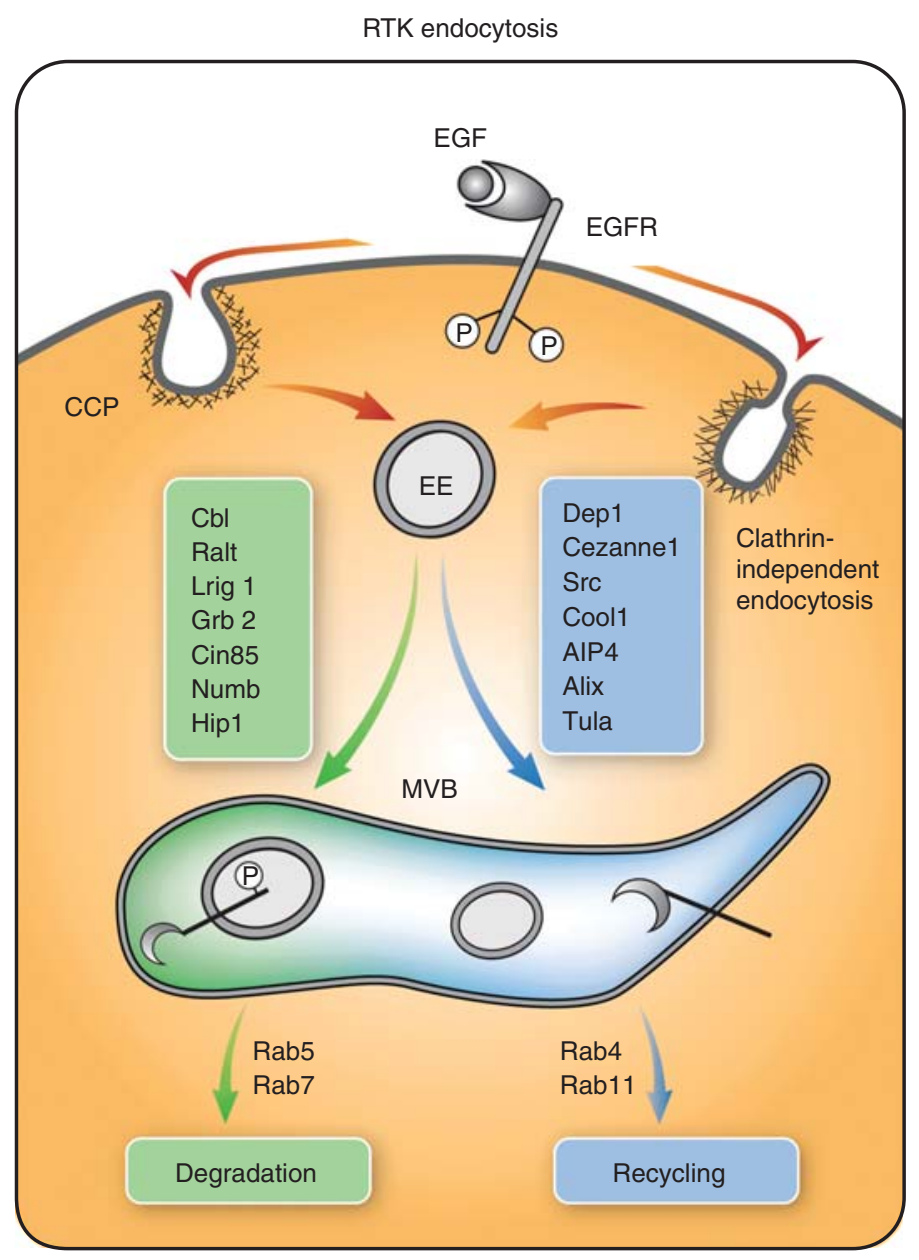

Figure 3. Protein complexes regulating endosomal sorting of RTKs. Following ligand-induced phosphorylation of RTKs, such as the EGF-receptor (EGFR), RTKs are internalized via clathrin-dependent and -independent pathways in a manner dependent on several accessory proteins, as listed. These pathways merge at the EE and feed multivesicular bodies (MVBs). Receptor sorting into internal vesicles of the MVB likely precedes delivery to lysosomes for degradation. Alternatively, receptors that remain confined to the limiting membrane of MVBs often recycle back to the plasma membrane, thereby engaging in repeated cycles of activation. Rab proteins, phosphatidylinositol modifying enzymes, and posttranslational modifications of both RTKs and endocytic adaptors, for example, phosphorylation (denoted as P), ubiquitination (Ub), and neddylation (conjugation of Nedd8), have critical roles in endosomal sorting. Specific players of each trafficking branch are indicated. Note that aberrant expression of some players, in a way that skews recycling, has been associated with human cancer (see list in Table 1).

\section{The EGFR/ErbB Family}

Four transmembrane receptor RTKs comprise the ErbB family, of which EGFR is the prototype. The 11 mammalian EGF-like ligands display wide variation in terms of receptor specificity, binding affinities, and dependence on $\mathrm{pH}$.
Likewise, multiple EGF-like ligands are encoded by smallpox viruses and, like the mammalian growth factors, they differ in their rate of clearance by means of receptor-mediated endocytosis (Tzahar et al. 1998). Ligands that are either sensitive to the low $\mathrm{pH}$ of endocytic compart- 
ments (e.g., transforming growth factor $\alpha$ ) or that bind EGFR with low affinity (e.g., epiregulin) are generally more sustained stimulants, and they often associate with human malignancies (Normanno et al. 2001). Conceivably, their ability to dissociate in EE favors receptor recycling, as opposed to transport to late endocytic compartments. Such factors are often autocrine in nature (Sporn and Todaro 1980), and provide one common mechanism that underlays constitutive proliferation by providing a sustained source of ligands that do not promote RTK down-regulation. Several additional mechanisms, which are briefly described below, may help cancer cells to evade regulation by RTK endocytosis.

\section{Receptor Overexpression}

Head and neck, brain, and other tumors often overexpress ErbB family members as a result of gene amplification or other mechanisms (Hynes and MacDonald 2009). This represents another mode that prolongs signaling; owing to the limited internalization capacity of the clathrin-coated pit and unbalanced ratio of cargoes versus endocytic adaptors, internalization of overexpressed EGFRs is either inhibited or preferentially followed by recycling (Wiley 1988; French et al. 1994). At the plasma membrane, overexpression also promotes the collision frequency of EGFR monomers, yielding the formation of dimers that are primed for ligand binding and signaling (Chung et al. 2010). Importantly, the four ErbB proteins form both homodimers and heterodimers, and each receptor combination follows different routing caused by the receptor's intrinsic internalization signals, association with ubiquitin ligases, and sensitivity of the ligand-receptor complex to low $\mathrm{pH}$. The closest kin of EGFR, an oncogenic coreceptor called HER2 or ErbB-2, is frequently overexpressed in some tumors, including $15 \%-20 \%$ of breast and gastric tumors. HER2 effectively escapes the endocytic pathway, because it binds no known ligand, lacks characteristic internalization signals, or HER2 molecules associate with heparin sulfate proteoglycans or plasma membrane microdomains that retain HER2 (Baulida et al. 1996; Pinkas-Kramarski et al. 1996). When HER2 is internalized, however, it rapidly recycles (Austin et al. 2004). In addition, when overexpressed, HER2 forms heterodimers with EGFR, which enhances recycling of both receptors (Lenferink et al. 1998; Worthylake et al. 1999), in part by reducing receptor ubiquitination (Levkowitz et al. 1996; Muthuswamy et al. 1999).

\section{Deletion Mutants of EGFR}

Approximately $50 \%$ of glial tumors harbor EGFR gene amplification (Wong et al. 1987), and a large fraction of these also present EGFRvIII (Jeuken et al. 2009), a deletion mutant lacking exons $2-7$, including a portion of the ligandbinding cleft. EGFRvIII molecules are basally dimerized and activated in the absence of ligand binding, thus conferring high tumorigenic potential (Nagane et al. 1996). In contrast to EGFR, EGFRvIII is inefficiently internalized and degraded, and after internalization it is recycled rather than delivered to lysosomes (Grandal et al. 2007). EGFRvIII binds the ubiquitin ligase $\mathrm{c}-\mathrm{Cbl}$ via Grb2, whereas binding via phosphorylated tyrosine residue 1045, the direct binding site of $\mathrm{Cbl}$, is limited, probably because EGFRvIII's tyrosine 1045 is hypophosphorylated (Han et al. 2006). Carboxy-terminal deletion mutants, collectively termed EGFRvIV, were also identified in brain tumors. Interestingly, the oncogenic function of both EGFRvIII and EGFRs harboring carboxy-terminal deletions depends on the chaperoning function of heat shock protein 90 (HSP90) (Lavictoire et al. 2003; Pines et al. 2010), and this feature is shared by another endocytosis-defective receptor, namely, HER2 (Citri et al. 2002; Neckers and Ivy 2003).

\section{Kinase Domain Mutants of EGFR}

Approximately $10 \%$ to $30 \%$ of tumors from patients with non-small-cell lung cancer (NSCLC) harbor somatic activating mutations in the gene encoding EGFR (Lynch et al. 2004; Paez et al. 2004; Pao et al. 2004). All mutations are restricted to the tyrosine kinase domain of EGFR. The most frequent point mutation is a substitution of an arginine for leucine at position 858 (L858R). Yet other mutants carry in- 
frame short deletions. Differential patterns of autophosphorylation resulting in enhanced Akt and Stat signaling have been associated with EGFR mutants (Sordella et al. 2004). Along with pathway-selective activation by EGFR mutants, their ligand-induced autophosphorylation decays relatively slowly (Lynch et al. 2004), raising the possibility that the mutant receptors evade degradation. Analyses of several mutants, including a double-mutant L858R/T790$\mathrm{M}$, which is resistant to tyrosine kinase inhibitors such as gefitinib and erlotinib, uncovered a defect in Cbl-mediated ubiquitination and degradation of EGFR (Shtiegman et al. 2007). The defect was attributed to a propensity of the mutants to heterodimerize with HER2, thereby evading c-Cbl-mediated ubiquitination. Consistent with this model, chromosomal analysis of lung tumors revealed that HER2 was amplified in $12 \%$ of tumors with acquired resistance to kinase inhibitors, versus only $1 \%$ of untreated patients with lung adenocarcinomas (Takezawa et al. 2012). Thus, activating mutants of EGFR in lung cancer exploit endocytosis-related mechanisms to reduce rapid inactivation by internalization and MVB sorting, further enhancing their oncogenic properties.

\section{Evasion of EGFR Feedback Regulators by Cancer Cells}

A major source of information on negative ErbB signals arises from developmental genetics of invertebrate organisms such as Caenorhabditis elegans and Drosophila. In C. elegans, loss of Sli-1, the ortholog of $\mathrm{Cbl}$ in mammals, leads to excessive vulva formation, and naturally occurring aberrant forms of c-Cbl are oncogenic in mammals (Thien and Langdon 2001; Kales et al. 2010). For example, DNA sequencing of leukemic bone marrow revealed a case with a c-Cbl point mutation (Cbl-R420Q) that inhibits internalization and ubiquitination of the Flt receptor (Sargin et al. 2007). In addition, mutations of Cbl-binding tyrosine in the cytoplasmic domain of the human-colony-stimulating factor-1 (CSF-1) receptor were found in children with secondary myelodysplasia and secondary acute myeloid leukemia (Ridge et al. 1990).
Similar to $\mathrm{Cbl}$ proteins, a group of negative EGFR regulators in insects undergo transcriptional up-regulation following activation of EGFR. For example, kekkon-1, which encodes a transmembrane protein, physically binds to and inhibits EGFR molecules (Ghiglione et al. 1999). Although the multiple Kekkon proteins of insects have no clear orthologs in mammals, the three mammalian LRIG proteins share domain organization with Kekkons. Moreover, LRIG1 physically associates with all four ErbB proteins of mammals and its up-regulation is followed by enhanced ubiquitination and degradation of EGFR. The underlying mechanism involves recruitment of c-Cbl, which simultaneously ubiquitinates EGFR and LRIG1, and sorts them for degradation (Gur et al. 2004; Laederich et al. 2004). In line with growth suppression, LRIG1 expression correlates with good prognosis of breast, cutaneous squamous cell carcinoma (SCC), and other types of cancer (Tanemura et al. 2005; Hedman and Henriksson 2007; Krig et al. 2011).

Like LRIG1, Mig6/RALT interacts with all ErbB members, along with additional RTKs, and blocks downstream signaling (Anastasi et al. 2003). Crystal structures of complexes between the EGFR kinase domain and a fragment of Mig6 showed binding to the distal surface of the C-lobe of the kinase domain (Zhang et al. 2007). Although the kinase region within such complexes is inactive, Mig6 nevertheless targets EGFR to endocytosis and degradation by recruiting a set of endocytic adaptors (e.g., AP-2 and intersectins) (Frosi et al. 2010). Presumably, Mig6 evolved as a suppressor of the inactive form of EGFR as a result of the scaffold, kinase-independent functions of EGFR and other RTKs. Interestingly, high-resolution genomic profiles of glial tumors identified a highly recurrent focal 1p36 deletion encompassing Mig6 (Ying et al. 2010), and high Mig6 expression in papillary thyroid cancer is associated with favorable outcomes (Ruan et al. 2008). In summary, the integration of in vitro lines of evidence and data from cancer patients attributes growthsuppressive functions to RTK endocytosis, but diverse and multiple aberrations weaken this mechanism in tumors. More examples of 
endocytosis-related proteins, which are aberrantly expressed in human tumors, are shown in Table 1.

\section{c-Met (Hepatocyte Growth Factor Receptor)}

In analogy to EGFR, c-Met is implicated in the growth, survival, and spread of various human cancers (Blumenschein et al. 2012). Overexpression of c-Met and autocrine HGF signaling are considered to be the two major aberrations of the HGF-Met axis in cancer, although rare mutations affecting several domains of the receptor have been documented that affect its behavior during endocytosis. For example, overexpression was observed in NSCLC, breast, renal, and ovarian cancer, and this has been associated with poor prognosis. Similarly, mutations in cMet were found in lymph-node metastases of head and neck squamous cell carcinomas, implying that the mutations are selected during metastatic spread (Di Renzo et al. 2000). Importantly, the juxtamembrane domain regulates ligand-dependent c-Met internalization by means of tyrosine-1003 phosphorylation in response to HGF binding, leading to c-Met ubiquitination and degradation (Abella et al. 2005). Thus, when an exon 14 deletion occurs, such as in lung and gastric cancer, the loss of Y1003 results in c-Met accumulation at the cell surface and persistent HGF stimulation, leading to tumorigenesis. Cbl's binding tyrosine is missing in another oncogenic mutant of c-Met, namely, the Tpr-Met fusion protein generated following a carcinogen-induced chromosomal rearrangement. As expected, this mutant is stable and cytoplasmic, undergoes no ubiquitination, and shows strong tumorigenesis (Mak et al. 2007). Differential ubiquitination and recruitment of Cbl proteins might underlie relatively strong signaling and transforming potential of other RTKs and their derivatives, such as Ret (Scott et al. 2005) and Flt-1 (Kobayashi et al. 2004).

\section{REDOX-REGULATED TRAFFICKING OF RTKS}

Aggressive cancer cells have high oxidative stress as a result of their acidic environment, which enhances the formation of reactive oxygen species (ROS) (Riemann et al. 2011). Another source of ROS is intrinsic; excessive activity of RTKs is known to produce free radicals (Lander 1997). Early observations found that hydrogen peroxide enhances EGFR phosphorylation on tyrosines (Gamou and Shimizu 1995) by a mechanism distinct from ligand-induced stimulation, in that no kinase activation is needed and phosphorylation is insensitive to EGFR kinase inhibitors (Filosto et al. 2011). Importantly, ROS-activated receptors undergo no ubiquitination or degradation. Instead, they translocate to a perinuclear location (most likely recycling endosomes) that permits sustained signaling (Khan et al. 2007). Evasion of receptor degradation, through mechanisms that likely involve Src activation and degradation of $\mathrm{Cbl}$ (Bao et al. 2003), seems to be common in tumors. Furthermore, it was shown that the gas phase of cigarette smoke contains hydrogen peroxide at doses sufficient to affect RTK function (Khan et al. 2007). Interestingly, under hypoxia, RTK signaling is commonly enhanced through transcription- or translation-mediated mechanisms. For instance, hypoxic microenvironments and activation of hypoxia-inducible factor (HIF) $2 \alpha$ in the core of solid tumors lead to overexpression of EGFR by increasing translation of the respective mRNA (Franovic et al. 2007). In addition, hypoxia prolongs the activation of EGFR because of lengthened receptor half-life and retention in the endocytic pathway. This is caused by the attenuation of Rab5-mediated EE fusion, via HIF-dependent down-regulation of a critical Rab5 effector, rabaptin-5, at the level of transcription (Wang et al. 2009). In conclusion, severe environmental conditions enhance RTK signaling by shunting receptor endocytosis, thereby enhancing signaling, cell survival, and tumorigenesis.

\section{THE SIGNALING ENDOSOME HYPOTHESIS}

Several lines of evidence support the possibility that RTKs and other receptors might generate signals while en route. Early studies identified active EGFRs and specific components of the Ras pathway in endosomes isolated from EGFstimulated livers (Di Guglielmo et al. 1994). 


$\underset{\substack{\text { PRSPECTIVES } \\ \mathbb{C}_{\infty}}}{\infty} \frac{\text { Cold Spring Harbor Perspectives in Biology }}{\text { www.cshperspectives.org }}$

Table 1. Endocytosis-regulating proteins aberrantly acting in human tumors

\begin{tabular}{|c|c|c|c|c|}
\hline Protein & Normal function & Defective function & Aberrations in human tumors & References \\
\hline Ack1 & $\begin{array}{l}\text { Binds clathrin, ubiquitin, and } \mathrm{Cdc} 42 \text {; } \\
\text { promotes EGFR degradation. }\end{array}$ & $\begin{array}{l}\text { The S985N mutant enhances proliferation and } \\
\text { stabilizes EGFR. Overexpression increases } \\
\text { metastasis. }\end{array}$ & $\begin{array}{l}\text { Gene amplification and overexpression in } \\
\text { lung ovarian and prostate cancers. Several } \\
\text { somatic and germline mutations. }\end{array}$ & $\begin{array}{l}\text { van der Horst et al. } \\
\text { 2005; Chua } \\
\text { et al. } 2010\end{array}$ \\
\hline Caveolin 1 & $\begin{array}{l}\text { Major coat protein of caveolae. } \\
\text { Invaginates lipid raft domains. Binds } \\
\text { with and enhances action of tumor } \\
\text { suppressor DLC1. }\end{array}$ & $\begin{array}{l}\text { Normally, caveolin inhibits several RTKs; deletion } \\
\text { of the fragile } 7 \mathrm{q} 31.1 \text { locus of caveolin } 1 \text { or gene } \\
\text { ablation enhances cell proliferation. }\end{array}$ & $\begin{array}{l}\text { Down-regulation and sporadic mutations } \\
\text { (e.g., P132 L) in breast, ovarian, and liver } \\
\text { cancer; up-regulated in kidney and } \\
\text { esophageal cancers. }\end{array}$ & $\begin{array}{l}\text { Goetz et al. 2008; } \\
\text { Du et al. } 2012\end{array}$ \\
\hline $\mathrm{Cbl}$ & An E3 ubiquitin ligase of several RTKs. & $\begin{array}{l}\text { Causes mutations in RING and linker domains, } \\
\text { deletions and insertion that inhibit receptor } \\
\text { ubiquitination. A viral short form is oncogenic. }\end{array}$ & Mutant forms in myeloid neoplasias. & $\begin{array}{l}\text { Sargin et al. 2007; } \\
\text { Kales et al. } 2010\end{array}$ \\
\hline
\end{tabular}

Clathrin Major component of the coat of membrane invaginations that mediate endocytosis.

Cortactin Links endocytosis to the actin
cytoskeleton by binding with actin and cytoskeleton by binding with actin
dynamin and activating Arp2/3.

Disabled 2 Cargo-selective clathrin adaptor that

(Dab2) binds Eps15 and intersectin; recruits myosin VI to clathrin-coated structure. Enables endocytosis of $\beta$ integrins.

Dynamin A large GTPase involved in endocytosis and cell migration. ubiquitination. Aviral short form is oncogenic

Constitutive activation of fusion partners such as the Alk kinase.

When overexpressed, inhibits EGFR ubiquitination and endocytosis.

Acts as a tumor suppressor by dictating tumor cell TGF- $\beta$ responses. Regulates EMT and recycling of TGF- $\beta$ receptors.

Dynamin 2 might be involved in preventing metastasis in carcinoma of the cervix, but in pancreatic cells, dynamin 2 potentiates metastasis.

Endophilin Induces membrane curvature during synaptic vesicle formation. Binds dynamin and synpatojanin.

The fusion protein containing a portion of endophilin, MLL-EEN, is nuclear rather than cytoplasmic; may interact with the Ras pathway.

Eps15

Endocytic adaptor for clathrin; promotes The coiled coil domain of Eps15 mediates endocytosis. oligomerization of a histone methyltransferase called MLL and enhances self-renewal of

A fusion protein found in inflammatory myofibroblastic tumors.

Bridge et al. 2001

Chromosomal amplification of 11q13 leads to overexpression in some tumors.

Overexpression in breast, head and neck, colorectal, liver, kidney, and brain tumors.

Down-regulated in ovarian, bladder, prostate, colorectal, and breast cancers. DAB2 promoter hypermethylation found in nasopharyngeal tumors.

Increased expression in tumors of the pancreas, but low expression correlates with lymph-node metastasis of cervix cancer.

Chromosomal translocation positions endophilin next to MLL (mixed lineage leukemia). The fusion protein is found in acute myeloid leukemia.

A fusion protein, Eps15-MLL is present in childhood leukemia.

Karam et al. 2007 Hannigan et al. 2010

Lee et al. 2010; Eppinga et al. 2012

So et al. 1997 hematopoietic progenitors. 
Table 1. Continued

\begin{tabular}{|c|c|c|c|c|}
\hline Protein & Normal function & Defective function & Aberrations in human tumors & References \\
\hline GEP100 & $\begin{array}{l}\text { A guanine-nucleotide exchange factor of } \\
\text { Arf6; binds active EGFRs. }\end{array}$ & Mediates metastasis in animal models. & $\begin{array}{l}\text { Overexpressed in invasive ductal carcinomas } \\
\text { of breast origins. Co-overexpression with } \\
\text { HER2 predicts nodal metastasis in primary } \\
\text { lung adenocarcinomas. }\end{array}$ & $\begin{array}{l}\text { Morishige et al. } \\
\text { 2008; Menju } \\
\text { et al. } 2011\end{array}$ \\
\hline HAX1 & $\begin{array}{l}\text { A multifunctional protein regulating } \\
\text { calcium homeostasis, cell migration, } \\
\text { and apoptosis. Binds with the tail of } \\
\alpha v \beta 6 \text {. }\end{array}$ & $\begin{array}{l}\text { In carcinoma cells, HAX1 enables cell invasion by } \\
\text { regulating endocytosis of integrin } \alpha v \beta 6 \text {. }\end{array}$ & $\begin{array}{l}\text { Up-regulation in melanoma, lung cancer, and } \\
\text { breast cancer. Mutations cause } \\
\text { neutropenia. }\end{array}$ & $\begin{array}{l}\text { Ramsay et al. 2007; } \\
\text { Trebinska et al. } \\
2010\end{array}$ \\
\hline HIP1 & $\begin{array}{l}\text { Coordinates actin remodeling during } \\
\text { formation of clathrin-coated vesicles. } \\
\text { Binds phosphoinositides, AP-2, and }\end{array}$ & $\begin{array}{l}\text { Induces cytokine-independent growth. Up- } \\
\text { regulates several RTKs. }\end{array}$ & $\begin{array}{l}\text { Overexpressed in gliomas and carcinomas of } \\
\text { the breast and prostate. A fusion protein, } \\
\text { HIP1-PDGFBR is found in CMML. }\end{array}$ & Rao et al. 2003 \\
\hline
\end{tabular}

Bins phosphoinositides, AP-2, and

clathrin.

Mdm2 A proto-oncogene that regulates p53 stability and ubiquitinates $\beta$ arrestins, mediators of internalization of Gprotein-coupled receptors.

NDRG1 A Rab4a effector protein that localizes to sorting vesicles by binding to phophatidylinositol 4-phosphate. Involved in recycling of E-cadherin.

Numb A multifunctional regulator of signaling by Notch, Hedgehog, and p53. Involved in endocytosis, determination of polarity, and migration.

Rab25 A rab11 family member that physically interacts with $\beta 1$ integrin and rescues lysosomally targeted integrins.

Likely regulates endocytosis of chemokine and other seven transmembrane receptors, along with negative feedback of $\mathrm{p} 53$.

Acquires oncogenicity through increased

Shenoy et al. 2001 expression in a range of common tumors (e.g., bladder cancer).

Acts as a metastasis suppressor in animal models. Down-regulated by N-Myc.

Down-regulated in prostate, breast, and pancreatic cancers.

Bandyopadhyay et al. 2003

Normally, Numb acts as an antagonist of Notch and a stabilizer of p53. In its absence, these pathways are altered and cells acquire malignant features.

Forced overexpression of Rab25 increases aggressiveness of cancer cells by activating the Akt pathway.

Down-regulated in breast and lung cancers.

Pece et al. 2004

Amplification of 1q22, centered on rab25, increases expression of Rab25 in breast (and ovarian) cancer and correlates with lymph-node metastasis.

RCP A Rab11 effector protein that associates with $\alpha 5 \beta 1$ integrin and guides

Recycling of EGFR and integrin $\alpha 5 \beta 1$ is normally inhibited by transcriptionally active TAp63, but recycling of integrins and EGFR.

Overexpressed in breast, ovarian, and head/
neck tumors. The respective $8 p 11-12$ locus

Cheng et al. 2004 Yin et al. 2012

Zhang et al. 2009 is frequently amplified in breast cancer. 
This implied that receptor endocytosis fulfills roles other than desensitization, in line with the decrease in Erk activation observed in cells expressing a dominant-negative mutant of dynamin (Vieira et al. 1996) as well as a loss of active Mek, the Erk-specific kinase, in cells lacking expression of an endosomal scaffold complex (MP1-p14) (Teis et al. 2002). Yet, cells expressing a mutant of dynamin showed enhanced DNA synthesis (Vieira et al. 1996), but a lowmolecular-weight inhibitor of dynamin inhibited, rather than enhanced, in vivo tumorigenesis of cells expressing a mutant form of c-Met thar led to the proposition that endosomal signaling enhances oncogenicity of c-Met (Joffre et al. 2011). Another inhibitory compound, of EGFR's kinase, was used to arrest EGFR in endosomes and derive evidence in support of endosomal signaling (Wang et al. 2002). Whereas it is widely accepted that signaling endosomes containing neurotrophins and their receptors are retrogradely transported along microtubules back to neuronal cell bodies, where they control transcriptional events (Howe and Mobley 2005), endosome signaling by EGFR and other receptors has received diverse interpretations. For example, spatially restricted phosphatases might regulate intracellular signaling. Accordingly, internalization of EGFR and signaling at sites in close proximity to the endoplasmic reticulum enable PTP1B-catalyzed dephosphorylation (Haj et al. 2002), whereas DEP-1, a transmembrane tyrosine phosphatase encoded by a tumor suppressor gene (Ruivenkamp et al. 2002), can prevent EGFR signaling at the plasma membrane, yet cannot inhibit endosomal signals (Tarcic et al. 2009). According to an alternative interpretation, EGFRs internalized via clathrin-mediated endocytosis are recycled to the cell surface, thus enabling EGFdependent DNA synthesis, but clathrin-independent internalization preferentially commits the receptor to degradation (Sigismund et al. 2008). Conceivably, better understanding of differential routings, along with heterogeneity at the level of EEs and selective engagement of endosomal scaffold proteins would throw light on intracellular signaling and its currently unclear contribution to tumor progression.

\section{ABERRANT INTEGRIN TRAFFICKING IN TUMORS}

Efficient cell migration requires constant endocytosis and recycling of integrins rather than their degradation. Accordingly, it was estimated that the plasma membrane pool of integrins is recycled through the endosomal system once in $30 \mathrm{~min}$ (Roberts et al. 2001), and this flux of integrins correlates with both migration speed (Teckchandani et al. 2009) and the overall dynamics of the plasma membrane (Mellman 1996a). Because integrin recycling is also important for cell division (cytokinesis) (Caswell et al. 2009), and integrins have major roles in tumor-stroma interactions, aberrant recycling of the 25 different integrin heterodimers is involved in tumor growth, invasion, metastasis, and evasion of apoptosis (Mosesson et al. 2008). One critical aspect of integrins' "outside-in signaling" is their ability to influence the manner in which RTKs respond to their ligands. For example, recycling of EGFR and integrin $\alpha 5 \beta 1$ is coordinated and this promotes cell migration in 3D matrices (Caswell et al. 2008).

The cycle of integrin endocytosis-exocytosis may initiate on inducible polymerization of tubulin, a well-known target for cancer therapies (Fig. 4). The growing tips of microtubules disintegrate focal adhesions and instigate dynamin-dependent endocytosis of some integrin heterodimers, in a mechanism that also requires the adaptor Dab2 and the kinase Fak (Ezratty et al. 2005). Internalized integrins follow three alternative routes: a short, Rab4-dependent recycling loop, a longer loop that depends on Rab11 family members and translocates cargoes to the perinuclear recycling endosomes, and a pathway leading to degradation in lysosomes. Although the details of the sorting process that takes place in dedicated vesicles located just behind the leading lamella (Pierini et al. 2000) are incompletely understood, it is clear that these routes are linked to tumor progression. For example, growth factors can shunt integrin $\alpha v \beta 3$ to the short recycling loop (Roberts et al. 2001) through a mechanism that requires $\mathrm{PKD}$-mediated phosphorylation of rabaptin, a binding partner of both Rab4 and Rab5 (Woods et al. 
I. Mellman and Y. Yarden

Focal adhesions

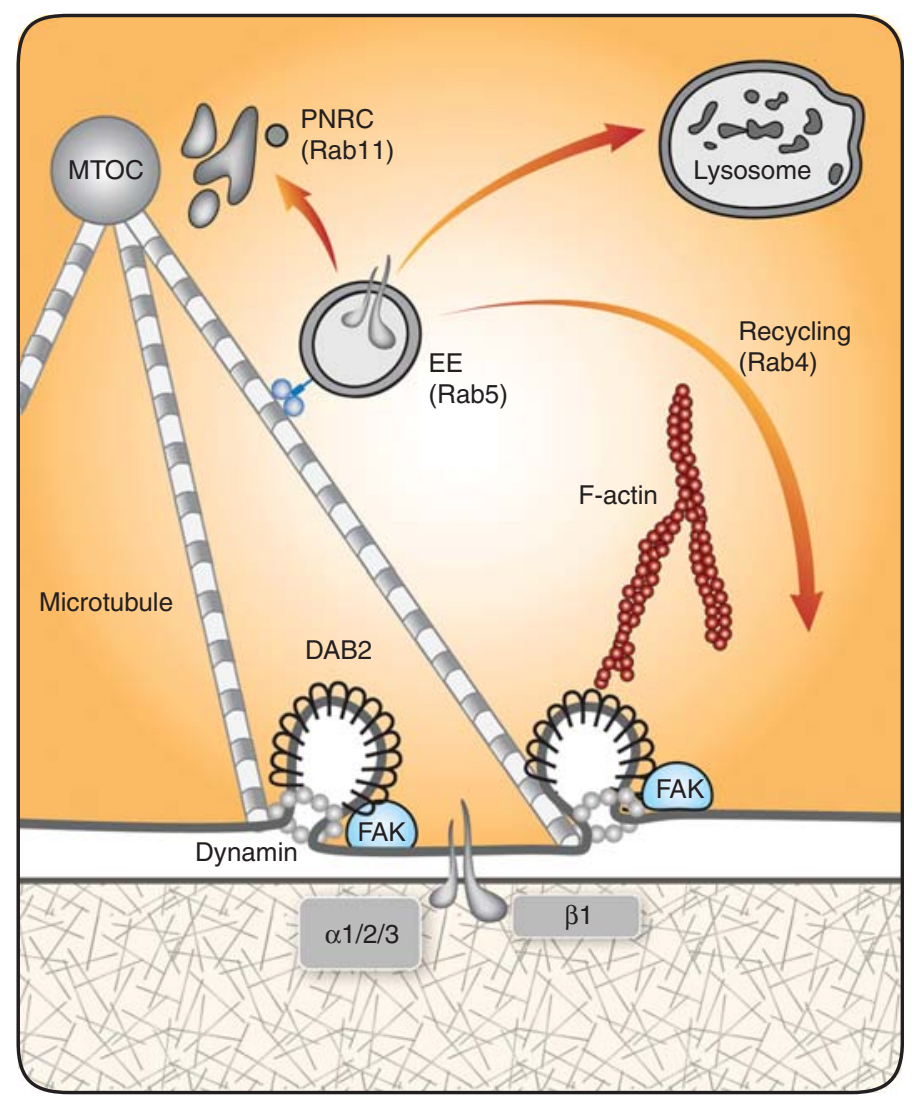

Figure 4. Endosomal sorting regulates integrin-based focal adhesions. Focal adhesions containing active conformers of integrin $\beta 1$ establish strong, yet dynamic, contacts between the ventral aspect of migrating cells and the underlying extracellular matrix. Both actin filaments and microtubules projecting from the microtubuleorganizing center (MTOC) regulate cell adhesion. The latter polymers dissolve focal adhesions once they approach the plasma membrane. This requires protein kinases, such as FAK, and recruitment of both dynamin 2 and disabled 2 (Dab2), a clathrin adaptor, which directly binds with the cytoplasmic tails of integrin $\beta$ subunits. Once internalized by activated dynamin, the formed clathrin-coated vesicles mature to integrinloaded EEs. These organelles are transported backward along microtubules to reach the PNRC and the recycling pathway, or these EEs deliver their cargo to lysosomes for degradation. These alternative itineraries are regulated by specific Rab proteins. Note that the flux of integrins through the endocytic pathway, rather than their surface levels, dictates migration speed. Accordingly, the levels of both Dab2 and dynamin display broad variation in several types of carcinomas (see Table 1).

2004; Christoforides et al. 2012). Likewise, another kinase, Akt/PKB, controls recycling of the $\alpha 5 \beta 1$ integrin through several downstream targets, including an Arf6-specific GTPase activating protein (GAP), ACAP1, which is needed for clathrin coat assembly (Li et al. 2005; 2007).

As already discussed, accelerated recycling of certain integrins characterizes cancer cells ex- pressing mutant forms of $\mathrm{p} 53$, and this involves the Rab-coupling protein (RCP) (Muller et al. 2012). Another driver of both integrin recycling and cancer is the epithelial member of the Rab11 family, Rab25. Early observations revealed overexpression of the respective gene in hepatocellular cancer (He et al. 2002) and later studies by the laboratory of Gordon Mills 
showed that amplification of 1q22, centered on rab25, increases expression of the GTPase in $\sim 50 \%$ of ovarian and breast cancers (Cheng et al. 2004). Furthermore, forced expression of Rab25 markedly increased anchorage-independent cell proliferation and enhanced aggressiveness of cancer cells in vivo. Other studies confirmed these observations (Brusegard et al. 2012) and also linked Rab25 to the group of androgen-responsive ovarian tumors (Sheach et al. 2009). These observations are consistent with the reported ability of Rab25 to physically interact with $\beta 1$ integrin (Caswell et al. 2007) and rescue lysosomally targeted integrins (Dozynkiewicz et al. 2012). Interestingly, the latter function involves a chloride channel, CLIC3, which is a marker for invasive, poor prognosis tumors of the pancreas. Thus, the wealth of currently available lines of information identifies vesicular transport of integrins as an important determinant of tumor progression.

\section{EMT AND ENDOCYTOSIS-MEDIATED DISRUPTION OF EPITHELIAL POLARITY IN TUMORS}

Epithelial-mesenchymal transition (EMT) represents the loss of cell-cell adhesions and apical-basal polarity, along with concomitant development of a motile phenotype (Thiery et al. 2009). Epithelial sheets acquire such phenotypes in the context of normal physiology, such as in embryogenesis and during tissue repair, as well as under pathological conditions that include organ fibrosis and metastasis formation (Kalluri and Weinberg 2009). To sustain EMT, cells apply a myriad of switches, both transcription-independent events such as vesicular trafficking as well as transcriptional switches involving newly synthesized macromolecules. The inducers of the switches are often soluble polypeptides, namely, chemokines and growth factors. The latter include HGF, Wnt, PDGF (platelet-derived growth factor), Notch ligands, and transforming growth factors. Importantly, both tight junctions and adherens junctions are lost during EMT. This is mediated by the suppression of junctional complexes (e.g., E-cadherin, ZO-1, occludins, and specific claudins) and components of polarity complexes, such as LGL2 (Fig. 5). The crucial part played by junctional complexes in cancer progression is exemplified by the frequent occurrence of genetic alterations in the epithelial cadherin (Ecadherin) in breast, gastric, colon, and other types of cancer (Paredes et al. 2012). Vesicular trafficking critically regulates junctional complexes by means of its polarizing function. For example, clathrin knockdown experiments performed with epithelial cells resulted in mislocalization of basolateral proteins, whereas the apical surface remained unaltered (Deborde et al. 2008). Polarity-maintaining trafficking is critically regulated by Cdc42 and the Par (partitioning-defective) group of proteins altered in cancer. For example, EGF was shown to regulate tight junction assembly by phosphorylation of Par3 (Wang et al. 2006), whereas HER2 disrupts epithelial polarity by binding to Par6 (Aranda et al. 2006).

The best understood components of adherens junctions are E-cadherins and their partners, the catenins. The exocytic pathway controls delivery of newly synthesized E-cadherin in complex with $\beta$-catenin, and this is regulated by sorting nexin 1 (SNX1) and Rab11 (Lock and Stow 2005). Additionally, the endocytic pathway controls E-cadherin, and this is regulated by Arf6, tyrosine kinases, and p120-catenin, the most potent inhibitor of E-cadherin endocytosis. The importance of E-cadherin trafficking is dual: At the surface, E-cadherin mediates cellto-cell homophilic interactions, but it also traps $\beta$-catenin. Loss of this interaction enables $\beta$ catenin to translocate to the nucleus, where it acts as an activator of the Wnt pathway. Hence, it comes as no surprise that multiple mechanisms regulate endocytosis of E-cadherin, and this bears clinical implications in oncology. The active form of Arf6, Arf6-GTP, recruits Nm23$\mathrm{H} 1$, a nucleoside diphosphate kinase that enhances fission of coated vesicles and causes internalization of E-cadherin (Palacios et al. 2002). In the same vein, EGFR interacts specifically with GEP100/BRAG2, an Arf6 guanine nucleotide exchange factor, to promote Arf6 activation and consequent E-cadherin internalization (Morishige et al. 2008). Interestingly, 
I. Mellman and Y. Yarden

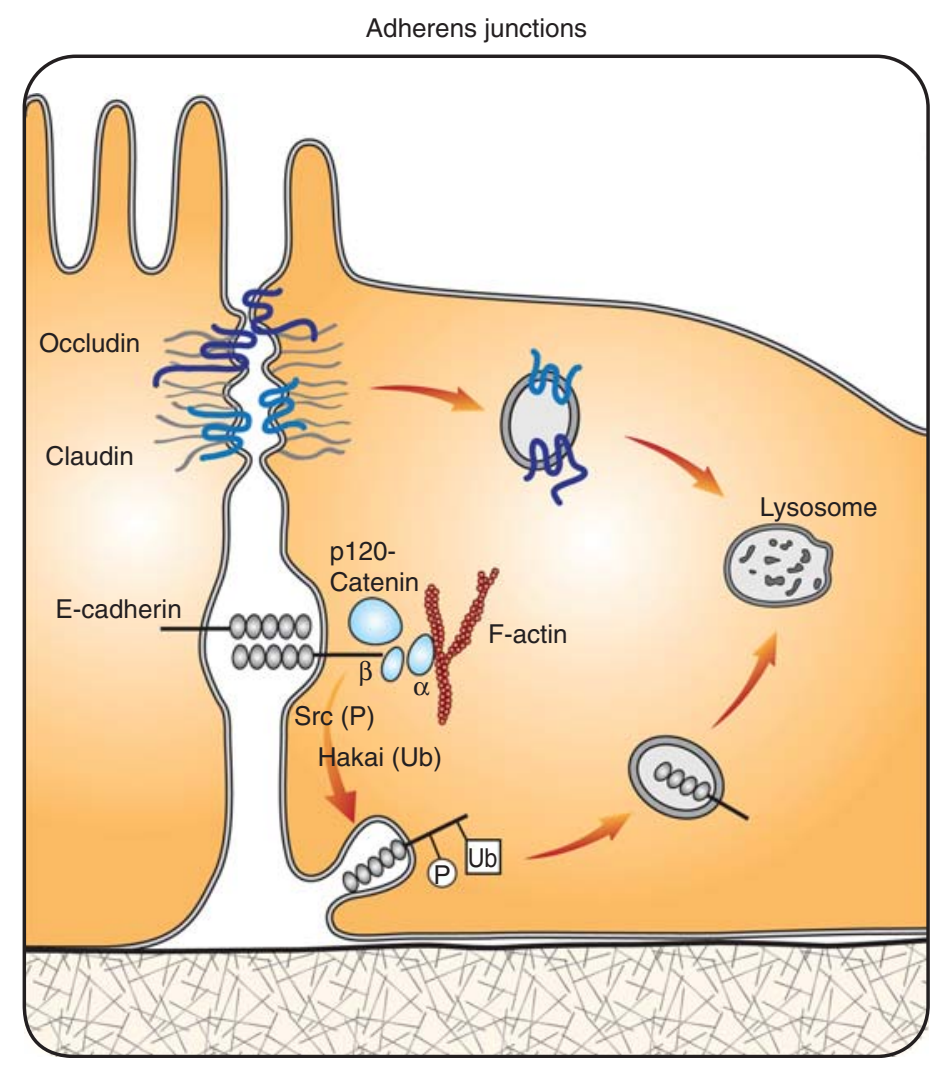

Figure 5. Endocytosis-mediated control of cell-to-cell junctions. Intact tight junctions and adherens junctions are essential for the integrity and polarity of epithelial sheets; their turnover is regulated by means of vesicular trafficking. Shown are two major components of tight junctions, occludin and claudin, and the epithelial cadherin, E-cadherin, the major component of adherens junctions. E-cadherin maintains calcium-dependent adhesion by means of homophilic extracellular interactions as well as association of the cytoplasmic tails with the actin cytoskeleton. This involves several types of catenins, including p120-catenin, an inhibitor of E-cadherin endocytosis. Tyrosine kinases such as Src have major roles in the disruption of adherens junctions; one mechanism involves inactivation of p120-catenin. Alternatively, tyrosine phosphorylation (denoted as $P$ ) of E-cadherin enables recognition by a Cbl-like ubiquitin ligase called Hakai that ubiquitinates (denoted as $U b$ ) and sorts E-cadherin molecules to lysosomal degradation. Low expression of E-cadherin, attributable to genetic and other reasons, characterizes a broad spectrum of advanced tumors.

co-overexpression of HER2 and GEP100 in lung tumors predicts metastasis in patients (Menju et al. 2011). Tyrosine kinases, such as Src or RTKs, also regulate trafficking of E-cadherin. Ubiquitination and trafficking to lysosomes of phosphorylated E-cadherin are mediated by Hakai, a Cbl-like E3 ubiquitin ligase. Hakai induces monoubiquitination of E-cadherin in response to Src activation (Fujita et al. 2002). Additionally, the viral form of Src stimulates Rab5 and Rab7, which target E-cadherin to lysosomes (Palacios et al. 2005). Along with phosphoryla- tion and regulation by growth factors, E-cadherin stability is strongly regulated by p120catenin (p120-ctn), which binds to the cytoplasmic portion of cadherins and inhibits their endocytosis. This is mediated by a dual-function motif consisting of three highly conserved acidic residues that serve as a p120-binding interface and an endocytic signal (Nanes et al. 2012).

Predictably, similarly detailed understanding of the endocytosis of other cell-to-cell adhesion molecules will not only deepen the way 
we conceive EMT but unravel molecules bearing prognostic value. It seems increasingly likely that maintenance of cell polarity may serve as one of the final brakes that suppress tumorigenesis.

\section{IMPLICATIONS OF DERAILED ENDOCYTOSIS TO CANCER THERAPY}

In theory, forced removal of endocytosis-defective oncogenic proteins, such as aberrant forms of certain receptors for growth factors, might inhibit tumor progression. This paradigm has been addressed using inhibitors of the heat shock protein 90 (HSP90), which stabilizes some oncogenic receptors at the cell surface, and one inhibitor, 17-allylamino-17-demethoxygeldanamycin (17-AAG, tanespimycin) has shown clinical activity in HER2-positive breast cancer (Neckers and Workman 2012). Similarly, kinase inhibitors that can specifically and covalently bind with HER2 and disassemble the HER2HSP90 complex, are able to target HER2 to degradation by the $26 \mathrm{~S}$ proteasome, thereby curtailing the transformed phenotype (Citri et al. 2002, 2004).

In contrast, monoclonal antibodies, by virtue of their intrinsic bivalence, might accelerate sorting of surface proteins to degradation in lysosomes, rather than in proteasomes. It is notable that recombinant antibodies targeting specific surface antigens of cancer cells are rapidly becoming the mainstay drugs in specific diseases, such as lymphoma and breast cancer (Ben-Kasus et al. 2007). Therapeutic antibodies almost invariably induce endocytosis of their antigens, and this attribute is already harnessed as a strategy to deliver cytotoxic payloads into cancer cells. For example, trastuzumab emtansine (T-DM1) is an antibody-drug conjugate incorporating the HER2-targeted antitumor properties of trastuzumab with the cytotoxic activity of the microtubule-inhibitory agent DM1. This drug significantly prolonged progression-free and overall survival of patients with HER2-positive advanced breast cancer (Verma et al. 2012). Importantly, the drug is designed to dissociate within the acidic endosomal compartment; hence, it acts as a Trojan horse that delivers chemotherapy.
Interestingly, combinations of monoclonal antibodies, each engaging a distinct epitope of the same antigen, synergistically induce receptor degradation and correspondingly collaborate in tumor inhibition. The underlying mechanism might comprise enhanced tumor cytotoxicity mediated by NK cells or macrophages that are engaged by the Fc tail of the antibodies (Spiridon et al. 2002). Alternatively, synergy might be the result of accelerated degradation of the antigen in lysosomes, a common consequence of receptor cross-linking (Mellman 1996b) as shown for HER2 (Friedman et al. 2005; Ben-Kasus et al. 2009) and EGFR (Pedersen et al. 2010; Koefoed et al. 2011). A study performed with combinations of antibodies to EGFR concluded that antibody pairs shunt internalized receptors from recycling to the degradative pathway (Spangler et al. 2010). Yet another study concluded that the endocytic pathway, although involving receptor ubiquitination, differs from the canonical ligand-induced route of RTK degradation (Ferraro et al. 2013). Notably, a combination of chemotherapy along with trastuzumab and another antibody to HER2 (pertuzumab), which binds with a nonoverlapping epitope, significantly prolonged progression-free survival of HER2positive breast cancer patients (Baselga et al. $2012 b$ ). Whether or not combinations of epitope-distinct antibodies to other surface antigens required for survival of cancer cells (e.g., c-Met and the receptor for insulin-like growth factor 1) will show similar synergy is an intriguing question that relates to the yet unclear endocytic route taken by immunocomplexes as well as the immunological differences between monoclonal and oligoclonal antibodies.

\section{CONCLUDING REMARKS AND FUTURE CHALLENGES}

It seems highly likely that derailed endocytosis can make major contributions to several hallmarks of cancer (Hanahan and Weinberg 2011). These include not only sustained proliferation of cancer cells, but also enhanced invasiveness and avoidance of apoptosis. In this vein, the effects of ROS on receptor endocytosis might 
translate to survival advantages while tumors undergo radiotherapy, chemotherapy, or angiogenesis therapy, but only a few studies have addressed these issues so far. This, along with the emerging multiplicity of cancer-related alterations of intracellular trafficking, underscore the absence of a universal model able to integrate the known sorting alterations with the wealth of currently available information on the stepwise accumulation of genetic aberrations during tumor progression. A systems biology approach to vesicular trafficking might delineate the required overarching model (Zwang and Yarden 2009). Accordingly, a hubcentric network controls cargo endocytosis. The typical hub contains a membrane-anchoring phosphoinositide-binding domain, a Rab protein, a ubiquitin-binding module that recruits ubiquitinated cargo, and machinery enabling homoassembly. Scheduled hub transitions, as well as membrane bending machineries, define points of commitment to vesicle budding and to unidirectional trafficking. Thus, to derail trafficking in a balanced way, oncogenic mechanisms might target Rab proteins as well as ubiquitin ligases and the overall homeostasis of phospholipids. Especially attractive are $3{ }^{\prime}$-phosphatidylinositol lipids, because several enzymes involved in phosphatidylinositol metabolism are mutationally altered in cancer. For example, PI3K and PTEN, which respectively increase and decrease intracellular levels of $3^{\prime}$ phosphoinositides, display oncogenic aberrations in a broad spectrum of tumors (Wong et al. 2010).

We propose that mutational effects on phosphoinositide lipids alter GTP loading of Rho and Rab proteins, and thereby finely bias endocytosis of RTKs and integrins in favor of recycling, rather than sorting for intracellular degradation. This is exemplified by the mechanism that activates Rac1:Rab5-mediated endocytosis positions Racl in endosomes, where it meets the GTP-exchange factor Tiam1 and later recycles to the plasma membrane in its active, GTPloaded form (Palamidessi et al. 2008). A similar trafficking mechanism that involves Arf6 localizes active Cdc42 at the cell leading edge, after GTP loading occurs within endosomes by the GEF called $\beta$ PIX (Osmani et al. 2010). Thus, future studies will likely describe endosomes as a nexus that permits oncogenic signals to tune endocytosis and recycle cargoes to specific domains of the cell surface. Endosomes already emerge as important signaling platforms, capable of controlling the amplitude and duration of oncogenic signals. Moreover, according to a recently proposed theory, by assembling alternative complexes of endocytic adaptors (e.g., Appll and SARA), endosomes might allow cross talk between distinct signaling pathways, such as the EGFR and the TGF- $\beta$ pathways (Osmani et al. 2010). Endosomal signaling and cross talk, along with trafficking-dependent activation of small GTPases and the putative pivotal roles of phosphoinositides, await in-depth understanding. High-resolution knowledge of the endosomal sorting-cancer interface may yet yield trafficking nodes amenable for therapeutic interception, but even if not, enhanced understanding will reveal how even subtle changes to the endocytic pathway can contribute disproportionately to the pathophysiology of cancer cells.

\section{REFERENCES}

Abella JV, Peschard P, Naujokas MA, Lin T, Saucier C, Urbe S, Park M. 2005. Met/Hepatocyte growth factor receptor ubiquitination suppresses transformation and is required for Hrs phosphorylation. Mol Cell Biol 25: 9632 9645.

Anastasi S, Fiorentino L, Fiorini M, Fraioli R, Sala G, Castellani L, Alema S, Alimandi M, Segatto O. 2003. Feedback inhibition by RALT controls signal output by the ErbB network. Oncogene 22: 4221-4234.

Aranda V, Haire T, Nolan ME, Calarco JP, Rosenberg AZ, Fawcett JP, Pawson T, Muthuswamy SK. 2006. Par6-aPKC uncouples ErbB2 induced disruption of polarized epithelial organization from proliferation control. Nat Cell Biol 8: $1235-1245$.

Austin CD, De Maziere AM, Pisacane PI, van Dijk SM, Eigenbrot C, Sliwkowski MX, Klumperman J, Scheller RH. 2004. Endocytosis and sorting of ErbB2 and the site of action of cancer therapeutics trastuzumab and geldanamycin. Mol Biol Cell 15: 5268-5282.

Balaji K, Mooser C, Janson CM, Bliss JM, Hojjat H, Colicelli J. 2012. RIN1 orchestrates the activation of RAB5 GTPases and ABL tyrosine kinases to determine the fate of EGFR. J Cell Sci 125: 5887-5896.

Bandyopadhyay S, Pai SK, Gross SC, Hirota S, Hosobe S, Miura K, Saito K, Commes T, Hayashi S, Watabe M, et al. 2003. The $\mathrm{Drg}-1$ gene suppresses tumor metastasis in prostate cancer. Cancer Res 63: 1731-1736. 
Bao J, Gur G, Yarden Y. 2003. Src promotes destruction of cCbl: Implications for oncogenic synergy between Src and growth factor receptors. Proc Natl Acad Sci 100: 2438 2443.

Bar-Sagi D, Feramisco JR. 1986. Induction of membrane ruffling and fluid-phase pinocytosis in quiescent fibroblasts by ras proteins. Science 233: 1061-1068.

Baselga J, Campone M, Piccart M, Burris HA 3rd, Rugo HS, Sahmoud T, Noguchi S, Gnant M, Pritchard KI, Lebrun F, et al. 2012a. Everolimus in postmenopausal hormonereceptor-positive advanced breast cancer. $N$ Engl J Med 366: $520-529$.

Baselga J, Cortes J, Kim SB, Im SA, Hegg R, Im YH, Roman L, Pedrini JL, Pienkowski T, Knott A, et al. 2012b. Pertuzumab plus trastuzumab plus docetaxel for metastatic breast cancer. N Engl J Med 366: 109-119.

Basu Roy UK, Henkhaus RS, Loupakis F, Cremolini C, Gerner EW, Ignatenko NA. 2012. Caveolin-1 is a novel regulator of K-RAS-dependent migration in colon carcinogenesis. Int J Cancer 133: 43-57.

Baulida J, Kraus MH, Alimandi M, Di Fiore PP, Carpenter G. 1996. All ErbB receptors other than the epidermal growth factor receptor are endocytosis impaired. $J$ Biol Chem 271: 5251-5257.

Ben-Kasus T, Schechter B, Sela M, Yarden Y. 2007. Cancer therapeutic antibodies come of age: Targeting minimal residual disease. Mol Oncol 1: 42-54.

Ben-Kasus T, Schechter B, Lavi S, Yarden Y, Sela M. 2009. Persistent elimination of ErbB-2/HER2-overexpressing tumors using combinations of monoclonal antibodies: Relevance of receptor endocytosis. Proc Natl Acad Sci 106: 3294-3299.

Blagosklonny MV. 2000. p53 from complexity to simplicity: Mutant p53 stabilization, gain-of-function, and dominant-negative effect. FASEB J 14: 1901-1907.

Blumenschein GR Jr, Mills GB, Gonzalez-Angulo AM. 2012. Targeting the hepatocyte growth factor-cMETaxis in cancer therapy. J Clin Oncol 30: 3287-3296.

Bridge JA, Kanamori M, Ma Z, Pickering D, Hill DA, Lydiatt W, Lui MY, Colleoni GW, Antonescu CR, Ladanyi M, et al. 2001. Fusion of the $A L K$ gene to the clathrin heavy chain gene, CLTC, in inflammatory myofibroblastic tumor. Am J Pathol 159: 411-415.

Brodsky FM. 2012. Diversity of clathrin function: New tricks for an old protein. Annu Rev Cell Dev Biol 28: 309-336.

Brusegard K, Stavnes HT, Nymoen DA, Flatmark K, Trope CG, Davidson B. 2012. Rab25 is overexpressed in Mullerian serous carcinoma compared to malignant mesothelioma. Virchows Arch 460: 193-202.

Cai JH, Zhao R, Zhu JW, Jin XL, Wan FJ, Liu K, Ji XP, Zhu YB, Zhu ZG. 2010. Expression of cortactin correlates with a poor prognosis in patients with stages II-III colorectal adenocarcinoma. J Gastrointest Surg 14: 1248-1257.

Caswell PT, Spence HJ, Parsons M, White DP, Clark K, Cheng KW, Mills GB, Humphries MJ, Messent AJ, Anderson KI, et al. 2007. Rab25 associates with $\alpha 5 \beta 1$ integrin to promote invasive migration in $3 \mathrm{D}$ microenvironments. Dev Cell 13: 496-510.

Caswell PT, Chan M, Lindsay AJ, McCaffrey MW, Boettiger D, Norman JC. 2008. Rab-coupling protein coordinates recycling of $\alpha 5 \beta 1$ integrin and EGFR1 to promote cell migration in 3D microenvironments. J Cell Biol 183: 143-155.

Caswell PT, Vadrevu S, Norman JC. 2009. Integrins: Masters and slaves of endocytic transport. Nat Rev Mol Cell Biol 10: $843-853$.

Cheng KW, Lahad JP, Kuo WL, Lapuk A, Yamada K, Auersperg N, Liu J, Smith-McCune K, Lu KH, Fishman D, et al. 2004. The RAB25 small GTPase determines aggressiveness of ovarian and breast cancers. Nat Med 10: 1251-1256.

Christoforides C, Rainero E, Brown KK, Norman JC, Toker A. 2012. PKD controls $\alpha v \beta 3$ integrin recycling and tumor cell invasive migration through its substrate Rabaptin-5. Dev Cell 23: 560-572.

Chua BT, Lim SJ, Tham SC, Poh WJ, Ullrich A. 2010. Somatic mutation in the ACK1 ubiquitin association domain enhances oncogenic signaling through EGFR regulation in renal cancer derived cells. Mol Oncol 4: 323334.

Chung I, Akita R, Vandlen R, Toomre D, Schlessinger J, Mellman I. 2010. Spatial control of EGF receptor activation by reversible dimerization on living cells. Nature 464: 783-787.

Citri A, Alroy I, Lavi S, Rubin C, Xu W, Grammatikakis N, Patterson C, Neckers L, Fry DW, Yarden Y. 2002. Druginduced ubiquitylation and degradation of ErbB receptor tyrosine kinases: Implications for cancer therapy. EMBO J 21: 2407-2417.

Citri A, Gan J, Mosesson Y, Vereb G, Szollosi J, Yarden Y 2004. Hsp90 restrains ErbB-2/HER2 signalling by limiting heterodimer formation. EMBO Rep 5: 1165-1170.

Deborde S, Perret E, Gravotta D, Deora A, Salvarezza S, Schreiner R, Rodriguez-Boulan E. 2008. Clathrin is a key regulator of basolateral polarity. Nature 452: 719723.

de la Vega M, Burrows JF, Johnston JA. 2011. Ubiquitination: Added complexity in Ras and Rho family GTPase function. Small GTPases 2: 192-201.

Di Guglielmo GM, Baass PC, Ou WJ, Posner BI, Bergeron JJ. 1994. Compartmentalization of SHC, GRB2 and mSOS, and hyperphosphorylation of Raf-1 by EGF but not insulin in liver parenchyma. EMBO J 13: 4269-4277.

Di Renzo MF, Olivero M, Martone T, Maffe A, Maggiora P, Stefani AD, Valente G, Giordano S, Cortesina G, Comoglio PM. 2000. Somatic mutations of the METoncogene are selected during metastatic spread of human HNSC carcinomas. Oncogene 19: 1547-1555.

Dozynkiewicz MA, Jamieson NB, Macpherson I, Grindlay J, van den Berghe PV, von Thun A, Morton JP, Gourley C, Timpson P, Nixon C, et al. 2012. Rab25 and CLIC3 collaborate to promote integrin recycling from late endosomes/lysosomes and drive cancer progression. Dev Cell 22: 131-145.

Du X, Qian X, Papageorge A, Schetter AJ, Vass WC, Liu X, Braverman R, Robles AI, Lowy DR. 2012. Functional interaction of tumor suppressor DLC1 and caveolin-1 in cancer cells. Cancer Res 72: 4405-4416.

Eppinga RD, Krueger EW, Weller SG, Zhang L, Cao H, McNiven MA. 2012. Increased expression of the large GTPase dynamin 2 potentiates metastatic migration and invasion of pancreatic ductal carcinoma. Oncogene 31: $1228-1241$. 
Ezratty EJ, Partridge MA, Gundersen GG. 2005. Microtubule-induced focal adhesion disassembly is mediated by dynamin and focal adhesion kinase. Nat Cell Biol 7: 581590.

Fang P, Zhao Z, Tian H, Zhang X. 2012. RIN1 exhibits oncogenic property to suppress apoptosis and its aberrant accumulation associates with poor prognosis in melanoma. Tumour Biol 33: 1511-1518.

Ferraro DA, Gaborit N, Maron R, Cohen-Dvashi H, Porat Z, Pareja F, Lavi S, Lindzen M, Ben-Chetrit N, Sela M, et al. 2013. Inhibition of triple-negative breast cancer models by combinations of antibodies to EGFR. Proc Natl Acad Sci 110: 1815-1820.

Filosto S, Khan EM, Tognon E, Becker C, Ashfaq M, Ravid T, Goldkorn T. 2011. EGF receptor exposed to oxidative stress acquires abnormal phosphorylation and aberrant activated conformation that impairs canonical dimerization. PloS ONE 6: e23240.

Franovic A, Gunaratnam L, Smith K, Robert I, Patten D, Lee S. 2007. Translational up-regulation of the EGFR by tumor hypoxia provides a nonmutational explanation for its overexpression in human cancer. Proc Natl Acad Sci 104: 13092-13097.

French AR, Sudlow GP, Wiley HS, Lauffenburger DA. 1994. Postendocytic trafficking of epidermal growth factor-receptor complexes is mediated through saturable and specific endosomal interactions. J Biol Chem 269: 1574915755.

Friedman LM, Rinon A, Schechter B, Lyass L, Lavi S, Bacus SS, Sela M, Yarden Y. 2005. Synergistic down-regulation of receptor tyrosine kinases by combinations of mAbs: Implications for cancer immunotherapy. Proc Natl Acad Sci 102: 1915-1920.

Frosi Y, Anastasi S, Ballaro C, Varsano G, Castellani L, Maspero E, Polo S, Alema S, Segatto O. 2010. A two-tiered mechanism of EGFR inhibition by RALT/MIG6 via kinase suppression and receptor degradation. J Cell Biol 189: $557-571$.

Fujita Y, Krause G, Scheffner M, Zechner D, Leddy HE Behrens J, Sommer T, Birchmeier W. 2002. Hakai, a cCbl-like protein, ubiquitinates and induces endocytosis of the E-cadherin complex. Nat Cell Biol 4: 222-231.

Gamou S, Shimizu N. 1995. Hydrogen peroxide preferentially enhances the tyrosine phosphorylation of epidermal growth factor receptor. FEBS Lett 357: 161-164.

Garrett WS, Chen LM, Kroschewski R, Ebersold M, Turley S, Trombetta S, Galan JE, Mellman I. 2000. Developmental control of endocytosis in dendritic cells by Cdc42. Cell 102: $325-334$.

Ghiglione C, Carraway KL 3rd, Amundadottir LT, Boswell RE, Perrimon N, Duffy JB. 1999. The transmembrane molecule kekkon 1 acts in a feedback loop to negatively regulate the activity of the Drosophila EGF receptor during oogenesis. Cell 96: 847-856.

Goetz JG, Lajoie P, Wiseman SM, Nabi IR. 2008. Caveolin-1 in tumor progression: The good, the bad and the ugly. Cancer Metastasis Rev 27: 715-735.

Goh LK, Huang F, Kim W, Gygi S, Sorkin A. 2010. Multiple mechanisms collectively regulate clathrin-mediated endocytosis of the epidermal growth factor receptor. J Cell Biol 189: 871-883.
Grandal MV, Zandi R, Pedersen MW, Willumsen BM, van Deurs B, Poulsen HS. 2007. EGFRvIII escapes down-regulation due to impaired internalization and sorting to lysosomes. Carcinogenesis 28: 1408-1417.

Gur G, Rubin C, Katz M, Amit I, Citri A, Nilsson J, Amariglio N, Henriksson R, Rechavi G, Hedman H, et al. 2004. LRIG1 restricts growth factor signaling by enhancing receptor ubiquitylation and degradation. $E M B O J$ 23: 3270-3281.

Haj FG, Verveer PJ, Squire A, Neel BG, Bastiaens PI. 2002. Imaging sites of receptor dephosphorylation by PTP1B on the surface of the endoplasmic reticulum. Science 295: $1708-1711$.

Han W, Zhang T, Yu H, Foulke JG, Tang CK. 2006. Hypophosphorylation of residue Y1045 leads to defective downregulation of EGFRvIII. Cancer Biol Ther 5: $1361-1368$.

Hanahan D, Weinberg RA. 2011. Hallmarks of cancer: The next generation. Cell 144: 646-674.

Hannigan A, Smith P, Kalna G, Lo Nigro C, Orange C, O'Brien DI, Shah R, Syed N, Spender LC, Herrera B, et al. 2010. Epigenetic downregulation of human disabled homolog 2 switches TGF- $\beta$ from a tumor suppressor to a tumor promoter. J Clin Invest 120: 2842-2857.

He H, Dai F, Yu L, She X, Zhao Y, Jiang J, Chen X, Zhao S. 2002. Identification and characterization of nine novel human small GTPases showing variable expressions in liver cancer tissues. Gene Expr 10: 231-242.

Hedman H, Henriksson R. 2007. LRIG inhibitors of growth factor signalling - Double-edged swords in human cancer? Eur J Cancer 43: 676-682.

Howe CL, Mobley WC. 2005. Long-distance retrograde neurotrophic signaling. Curr Opin Neurobiol 15: 40-48.

Hsu JM, Chen CT, Chou CK, Kuo HP, Li LY, Lin CY, Lee HJ, Wang YN, Liu M, Liao HW, et al. 2011. Crosstalk between Arg 1175 methylation and Tyr 1173 phosphorylation negatively modulates EGFR-mediated ERK activation. Nature Cell Biol 13: 174-181.

Huotari J, Helenius A. 2011. Endosome maturation. EMBO J 30: 3481-3500.

Hynes NE, MacDonald G. 2009. ErbB receptors and signaling pathways in cancer. Curr Opin Cell Biol 21: 177-184.

Jeuken J, Sijben A, Alenda C, Rijntjes J, Dekkers M, BootsSprenger S, McLendon R, Wesseling P. 2009. Robust detection of EGFR copy number changes and EGFR variant III: Technical aspects and relevance for glioma diagnostics. Brain Pathol 19: 661-671.

Jewell JL, Russell RC, Guan KL. 2013. Amino acid signalling upstream of mTOR. Nat Rev Mol Cell Biol 14: 133-139.

Joffre C, Barrow R, Menard L, Calleja V, Hart IR, Kermorgant S. 2011. A direct role for Met endocytosis in tumorigenesis. Nat Cell Biol 13: 827-837.

Jura N, Bar-Sagi D. 2006. Mapping cellular routes of Ras: A ubiquitin trail. Cell Cycle 5: 2744-2747.

Kales SC, Ryan PE, Nau MM, Lipkowitz S. 2010. Cbl and human myeloid neoplasms: The $\mathrm{Cbl}$ oncogene comes of age. Cancer Res 70: 4789-4794.

Kalluri R, Weinberg RA. 2009. The basics of epithelial-mesenchymal transition. J Clin Invest 119: 1420-1428.

Karam JA, Shariat SF, Huang HY, Pong RC, Ashfaq R, Shapiro E, Lotan Y, Sagalowsky AI, Wu XR, Hsieh JT. 2007. 
Decreased DOC-2/DAB2 expression in urothelial carcinoma of the bladder. Clin Cancer Res 13: 4400-4406.

Katzmann DJ, Babst M, Emr SD. 2001. Ubiquitin-dependent sorting into the multivesicular body pathway requires the function of a conserved endosomal protein sorting complex, ESCRT-I. Cell 106: 145-155.

Khan EM, Lanir R, Danielson AR, Goldkorn T. 2007. Epidermal growth factor receptor exposed to cigarette smoke is aberrantly activated and undergoes perinuclear trafficking. FASEB J 22: 910-917.

Kobayashi S, Sawano A, Nojima Y, Shibuya M, Maru Y. 2004. The c-Cbl/CD2AP complex regulates VEGF-induced endocytosis and degradation of Flt-1 (VEGFR-1). FASEB J 18: 929-931.

Koefoed K, Steinaa L, Soderberg JN, Kjaer I, Jacobsen HJ, Meijer PJ, Haurum JS, Jensen A, Kragh M, Andersen PS, et al. 2011. Rational identification of an optimal antibody mixture for targeting the epidermal growth factor receptor. MAbs 3: 584-595.

Krig SR, Frietze S, Simion C, Miller JK, Fry WH, Rafidi H, Kotelawala L, Qi L, Griffith OL, Gray JW, et al. 2011. Lrig1 is an estrogen-regulated growth suppressor and correlates with longer relapse-free survival in ER $\alpha$-positive breast cancer. Mol Cancer Res 9: 1406-1417.

Laederich MB, Funes-Duran M, Yen L, Ingalla E, Wu X, Carraway KL III, Sweeney C. 2004. The leucine-rich repeat protein LRIG1 is a negative regulator of ErbB family receptor tyrosine kinases. J Biol Chem 279: 47050-47056.

Lander HM. 1997. An essential role for free radicals and derived species in signal transduction. FASEB J 11: 118 124.

Laplante M, Sabatini DM. 2012. mTOR signaling in growth control and disease. Cell 149: 274-293.

Lavictoire SJ, Parolin DA, Klimowicz AC, Kelly JF, Lorimer IA. 2003. Interaction of Hsp90 with the nascent form of the mutant epidermal growth factor receptor EGFRvIII. J Biol Chem 278: 5292-5299.

Lee YY, Do IG, Park YA, Choi JJ, Song SY, Kim CJ, Kim MK, Song TJ, Park HS, Choi CH, et al. 2010. Low dynamin 2 expression is associated with tumor invasion and metastasis in invasive squamous cell carcinoma of cervix. Cancer Biol Ther 10: 329-335.

Lenferink AE, Pinkas-Kramarski R, van de Poll ML, van Vugt MJ, Klapper LN, Tzahar E, Waterman H, Sela M, van Zoelen EJ, Yarden Y. 1998. Differential endocytic routing of homo- and hetero-dimeric ErbB tyrosine kinases confers signaling superiority to receptor heterodimers. EMBO J 17: 3385-3397.

Letessier A, Sircoulomb F, Ginestier C, Cervera N, Monville F, Gelsi-Boyer V, Esterni B, Geneix J, Finetti P, Zemmour C, et al. 2006. Frequency, prognostic impact, and subtype association of $8 \mathrm{p} 12,8 \mathrm{q} 24,11 \mathrm{q} 13,12 \mathrm{p} 13,17 \mathrm{q} 12$, and $20 \mathrm{q} 13$ amplifications in breast cancers. BMC Cancer 6: 245.

Levkowitz G, Klapper LN, Tzahar E, Freywald A, Sela M, Yarden Y. 1996. Coupling of the $\mathrm{c}$ - $\mathrm{Cbl}$ protooncogene product to ErbB-1/EGF-receptor but not to other ErbB proteins. Oncogene 12: 1117-1125.

Levkowitz G, Waterman H, Zamir E, Kam Z, Oved S, Langdon WY, Beguinot L, Geiger B, Yarden Y. 1998. c-Cbl/Sli1 regulates endocytic sorting and ubiquitination of the epidermal growth factor receptor. Genes Dev 12: 3663 3674.

Li L, Cohen SN. 1996. Tsg101: A novel tumor susceptibility gene isolated by controlled homozygous functional knockout of allelic loci in mammalian cells. Cell 85: 319-329.

Li J, Ballif BA, Powelka AM, Dai J, Gygi SP, Hsu VW. 2005. Phosphorylation of ACAP1 by Akt regulates the stimulation-dependent recycling of integrin $\beta 1$ to control cell migration. Dev Cell 9: 663-673.

Li J, Peters PJ, Bai M, Dai J, Bos E, Kirchhausen T, Kandror KV, Hsu VW. 2007. An ACAP1-containing clathrin coat complex for endocytic recycling. J Cell Biol 178: 453-464.

Lock JG, Stow JL. 2005. Rab11 in recycling endosomes regulates the sorting and basolateral transport of E-cadherin. Mol Biol Cell 16: 1744-1755.

Lu A, Tebar F, Alvarez-Moya B, Lopez-Alcala C, Calvo M, Enrich C, Agell N, Nakamura T, Matsuda M, Bachs O. 2009. A clathrin-dependent pathway leads to KRas signaling on late endosomes en route to lysosomes. J Cell Biol 184: 863-879.

Lynch TJ, Bell DW, Sordella R, Gurubhagavatula S, Okimoto RA, Brannigan BW, Harris PL, Haserlat SM, Supko JG, Haluska FG, et al. 2004. Activating mutations in the epidermal growth factor receptor underlying responsiveness of non-small-cell lung cancer to gefitinib. $N$ Engl J Med 350: 2129-2139.

Mak HH, Peschard P, Lin T, Naujokas MA, Zuo D, Park M. 2007. Oncogenic activation of the Met receptor tyrosine kinase fusion protein, Tpr-Met, involves exclusion from the endocytic degradative pathway. Oncogene 26: 72137221.

Mayor S, Parton RG, Donaldson JG. 2014. Clathrin-independent pathways of endocytosis. Cold Spring Harb Perspect Biol doi: 10.1101/cshperspect.a016758.

Mellman I. 1996a. Endocytosis and molecular sorting. Annu Rev Cell Dev Biol 12: 575-625.

Mellman I. 1996b. Membranes and sorting. Curr Opin Cell Biol 8: 497-498.

Menju T, Hashimoto S, Hashimoto A, Otsuka Y, Handa H, Ogawa E, Toda Y, Wada H, Date H, Sabe H. 2011. Engagement of overexpressed Her2 with GEP100 induces autonomous invasive activities and provides a biomarker for metastases of lung adenocarcinoma. PloS ONE 6: e25301.

Mills GB, Jurisica I, Yarden Y, Norman JC. 2009. Genomic amplicons target vesicle recycling in breast cancer. J Clin Invest 119: 2123-2127.

Morishige M, Hashimoto S, Ogawa E, Toda Y, Kotani H, Hirose M, Wei S, Hashimoto A, Yamada A, Yano H, et al. 2008. GEP100 links epidermal growth factor receptor signalling to Arf6 activation to induce breast cancer invasion. Nat Cell Biol 10: 85-92.

Mosesson Y, Mills GB, Yarden Y. 2008. Derailed endocytosis: An emerging feature of cancer. Nat Rev Cancer 8: 835850.

Muller PAJ, Caswell PT, Doyle B, Iwanicki MP, Tan EH, Karim S, Lukashchuk N, Gillespie DA, Ludwig RL, Gosseline P, et al. 2010. Mutant p53 drives invasion by promoting integrin recycling. Cell 139: 1327-1341. 
Muller PA, Trinidad AG, Timpson P, Morton JP, Zanivan S, van den Berghe PV, Nixon C, Karim SA, Caswell PT, Noll JE, et al. 2012. Mutant p53 enhances MET trafficking and signalling to drive cell scattering and invasion. Oncogene 32: $1252-1265$.

Muthuswamy SK, Gilman M, Brugge JS. 1999. Controlled dimerization of ErbB receptors provides evidence for differential signaling by homo- and heterodimers. Mol Cell Biol 19: 6845-6857.

Nagane M, Coufal F, Lin H, Bogler O, Cavenee WK, Huang HJ. 1996. A common mutant epidermal growth factor receptor confers enhanced tumorigenicity on human glioblastoma cells by increasing proliferation and reducing apoptosis. Cancer Res 56: 5079-5086.

Nanes BA, Chiasson-MacKenzie C, Lowery AM, Ishiyama N, Faundez V, Ikura M, Vincent PA, Kowalczyk AP. 2012. p120-catenin binding masks an endocytic signal conserved in classical cadherins. J Cell Biol 199: 365-380.

Neckers L, Ivy SP. 2003. Heat shock protein 90. Curr Opin Oncol 15: 419-424.

Neckers L, Workman P. 2012. Hsp90 molecular chaperone inhibitors: Are we there yet? Clin Cancer Res 18: 64-76.

Normanno N, Bianco C, De Luca A, Salomon DS. 2001. The role of EGF-related peptides in tumor growth. Front Biosci 6: D685-D707.

Oren M, Rotter V. 2010. Mutant p53 gain-of-function in cancer. Cold Spring Harb Perspect Biol 2: a001107.

Osmani N, Peglion F, Chavrier P, Etienne-Manneville S. 2010. Cdc42 localization and cell polarity depend on membrane traffic. J Cell Biol 191: 1261-1269.

Paez JG, Janne PA, Lee JC, Tracy S, Greulich H, Gabriel S, Herman P, Kaye FJ, Lindeman N, Boggon TJ, et al. 2004. EGFR mutations in lung cancer: Correlation with clinical response to gefitinib therapy. Science 304: 1497-1500.

Palacios F, Schweitzer JK, Boshans RL, D'Souza-Schorey C. 2002. ARF6-GTP recruits Nm23-H1 to facilitate dynamin-mediated endocytosis during adherens junctions disassembly. Nat Cell Biol 4: 929-936.

Palacios F, Tushir JS, Fujita Y, D'Souza-Schorey C. 2005. Lysosomal targeting of E-cadherin: A unique mechanism for the down-regulation of cell-cell adhesion during epithelial to mesenchymal transitions. Mol Cell Biol 25: 389-402.

Palamidessi A, Frittoli E, Garre M, Faretta M, Mione M, Testa I, Diaspro A, Lanzetti L, Scita G, Di Fiore PP. 2008. Endocytic trafficking of Rac is required for the spatial restriction of signaling in cell migration. Cell 134: $135-147$.

Pao W, Miller V, Zakowski M, Doherty J, Politi K, Sarkaria I, Singh B, Heelan R, Rusch V, Fulton L, et al. 2004. EGF receptor gene mutations are common in lung cancers from "never smokers" and are associated with sensitivity of tumors to gefitinib and erlotinib. Proc Natl Acad Sci 101: 13306-13311.

Parachoniak CA, Park M. 2012. Dynamics of receptor trafficking in tumorigenicity. Trends Cell Biol 22: 231-240.

Parachoniak CA, Luo Y, Abella JV, Keen JH, Park M. 2011. GGA3 functions as a switch to promote Met receptor recycling, essential for sustained ERK and cell migration. Dev Cell 20: 751-763.
Paredes J, Figueiredo J, Albergaria A, Oliveira P, Carvalho J, Ribeiro AS, Caldeira J, Costa AM, Simoes-Correia J, Oliveira MJ, et al. 2012. Epithelial E- and P-cadherins: Role and clinical significance in cancer. Biochim Biophys Acta 1826: $297-311$.

Pece S, Serresi M, Santolini E, Capra M, Hulleman E, Galimberti V, Zurrida S, Maisonneuve P, Viale G, Di Fiore PP. 2004. Loss of negative regulation by Numb over Notch is relevant to human breast carcinogenesis. J Cell Biol 167: 215-221.

Pedersen MW, Jacobsen HJ, Koefoed K, Hey A, Pyke C, Haurum JS, Kragh M. 2010. Sym004: A novel synergistic anti-epidermal growth factor receptor antibody mixture with superior anticancer efficacy. Cancer Res 70: 588 597.

Pierini LM, Lawson MA, Eddy RJ, Hendey B, Maxfield FR. 2000. Oriented endocytic recycling of $\alpha 5 \beta 1$ in motile neutrophils. Blood 95: 2471-2480.

Pines G, Huang PH, Zwang Y, White FM, Yarden Y. 2010. EGFRvIV: A previously uncharacterized oncogenic mutant reveals a kinase autoinhibitory mechanism. Oncogene 29: 5850-5860.

Pinkas-Kramarski R, Soussan L, Waterman H, Levkowitz G, Alroy I, Klapper L, Lavi S, Seger R, Ratzkin BJ, Sela M, et al. 1996. Diversification of Neu differentiation factor and epidermal growth factor signaling by combinatorial receptor interactions. EMBO J 15: 2452-2467.

Piper RC, Dikic I, Lukacs G. 2014. Ubiquitin-dependent sorting in endocytosis. Cold Spring Harb Perspect Biol doi: $10.1101 /$ cshperspect.a016808.

Pylayeva-Gupta Y, Grabocka E, Bar-Sagi D. 2011. RAS oncogenes: Weaving a tumorigenic web. Nat Rev Cancer 11: 761-774.

Raiborg C, Stenmark H. 2009. The ESCRT machinery in endosomal sorting of ubiquitylated membrane proteins. Nature 458: 445-452.

Ramsay AG, Keppler MD, Jazayeri M, Thomas GJ, Parsons M, Violette S, Weinreb P, Hart IR, Marshall JF. 2007. HS1associated protein $\mathrm{X}-1$ regulates carcinoma cell migration and invasion via clathrin-mediated endocytosis of integrin $\alpha v \beta 6$. Cancer Res 67: 5275-5284.

Rao DS, Bradley SV, Kumar PD, Hyun TS, Saint-Dic D, Oravecz-Wilson K, Kleer CG, Ross TS. 2003. Altered receptor trafficking in Huntingtin Interacting Protein 1transformed cells. Cancer Cell 3: 471-482.

Ridge SA, Worwood M, Oscier D, Jacobs A, Padua RA. 1990. FMS mutations in myelodysplastic, leukemic, and normal subjects. Proc Natl Acad Sci 87: 1377-1380.

Riemann A, Schneider B, Ihling A, Nowak M, Sauvant C, Thews O, Gekle M. 2011. Acidic environment leads to ROS-induced MAPK signaling in cancer cells. PloS ONE 6: e22445.

Roberts M, Barry S, Woods A, van der Sluijs P, Norman J. 2001. PDGF-regulated rab4-dependent recycling of $\alpha v \beta 3$ integrin from early endosomes is necessary for cell adhesion and spreading. Curr Biol 11: 1392-1402.

Rogaia D, Grignani F, Carbone R, Riganelli D, LoCoco F, Nakamura T, Croce CM, Di Fiore PP, Pelicci PG. 1997. The localization of the HRX/ALL1 protein to specific nuclear subdomains is altered by fusion with its eps 15 translocation partner. Cancer Res 57: 799-802. 
Roy S, Wyse B, Hancock JF. 2002. H-Ras signaling and K-Ras signaling are differentially dependent on endocytosis. Mol Cell Biol 22: 5128-5140.

Ruan DT, Warren RS, Moalem J, Chung KW, Griffin AC, Shen W, Duh QY, Nakakura E, Donner DB, Khanafshar E, et al. 2008. Mitogen-inducible gene-6 expression correlates with survival and is an independent predictor of recurrence in $\mathrm{BRAF}^{\mathrm{V} 600 \mathrm{E}}$ positive papillary thyroid cancers. Surgery 144: 908-913; discussion 913-904.

Ruivenkamp CA, van Wezel T, Zanon C, Stassen AP, Vlcek C, Csikos T, Klous AM, Tripodis N, Perrakis A, Boerrigter L, et al. 2002. Ptprj is a candidate for the mouse coloncancer susceptibility locus $\mathrm{Sccl}$ and is frequently deleted in human cancers. Nat Genet 31: 295-300.

Sargin B, Choudhary C, Crosetto N, Schmidt MH, Grundler R, Rensinghoff M, Thiessen C, Tickenbrock L, Schwable J, Brandts C, et al. 2007. Flt3-dependent transformation by inactivating c-Cbl mutations in AML. Blood 110: 10041012.

Sasaki AT, Carracedo A, Locasale JW, Anastasiou D, Takeuchi K, Kahoud ER, Haviv S, Asara JM, Pandolfi PP, Cantley LC. 2011. Ubiquitination of K-Ras enhances activation and facilitates binding to select downstream effectors. Sci Sig 4: ra13.

Scott RP, Eketjall S, Aineskog H, Ibanez CF. 2005. Distinct turnover of alternatively spliced isoforms of the RET kinase receptor mediated by differential recruitment of the Cbl ubiquitin ligase. J Biol Chem 280: 13442-13449.

Senda K, Goi T, Hirono Y, Katayama K, Yamaguchi A. 2007. Analysis of RIN1 gene expression in colorectal cancer. Oncol Rep 17: 1171-1175.

Sheach LA, Adeney EM, Kucukmetin A, Wilkinson SJ, Fisher AD, Elattar A, Robson CN, Edmondson RJ. 2009. Androgen-related expression of G-proteins in ovarian cancer. Br J Cancer 101: 498-503.

Shenoy SK, McDonald PH, Kohout TA, Lefkowitz RJ. 2001. Regulation of receptor fate by ubiquitination of activated $\beta 2$-adrenergic receptor and $\beta$-arrestin. Science 294: 1307-1313.

Shtiegman K, Kochupurakkal BS, Zwang Y, Pines G, Starr A, Vexler A, Citri A, Katz M, Lavi S, Ben-Basat Y, et al. 2007. Defective ubiquitinylation of EGFR mutants of lung cancer confers prolonged signaling. Oncogene 26: 6968-6978.

Sigismund S, Woelk T, Puri C, Maspero E, Tacchetti C, Transidico P, Di Fiore PP, Polo S. 2005. Clathrin-independent endocytosis of ubiquitinated cargos. Proc Natl Acad Sci 102: $2760-2765$.

Sigismund S, Argenzio E, Tosoni D, Cavallaro E, Polo S, Di Fiore PP. 2008. Clathrin-mediated internalization is essential for sustained EGFR signaling but dispensable for degradation. Dev Cell 15: 209-219.

So CW, Caldas C, Liu MM, Chen SJ, Huang QH, Gu LJ, Sham MH, Wiedemann LM, Chan LC. 1997. EEN encodes for a member of a new family of proteins containing an Src homology 3 domain and is the third gene located on chromosome 19p13 that fuses to MLL in human leukemia. Proc Natl Acad Sci 94: 2563-2568.

Sordella R, Bell DW, Haber DA, Settleman J. 2004. Gefitinibsensitizing EGFR mutations in lung cancer activate antiapoptotic pathways. Science 305: 1163-1167.
Sorkin A, von Zastrow M. 2009. Endocytosis and signalling: Intertwining molecular networks. Nat Rev Mol Cell Biol 10: $609-622$.

Spangler JB, Neil JR, Abramovitch S, Yarden Y, White FM, Lauffenburger DA, Wittrup KD. 2010. Combination antibody treatment down-regulates epidermal growth factor receptor by inhibiting endosomal recycling. Proc Natl Acad Sci 107: 13252-13257.

Spiridon CI, Ghetie MA, Uhr J, Marches R, Li JL, Shen GL, Vitetta ES. 2002. Targeting multiple Her-2 epitopes with monoclonal antibodies results in improved antigrowth activity of a human breast cancer cell line in vitro and in vivo. Clin Cancer Res 8: 1720-1730.

Sporn MB, Todaro GJ. 1980. Autocrine secretion and malignant transformation of cells. N Engl J Med 303: 878880.

Takezawa K, Pirazzoli V, Arcila ME, Nebhan CA, Song X, de Stanchina E, Ohashi K, Janjigian YY, Spitzler PJ, Melnick MA, et al. 2012. HER2 amplification: A potential mechanism of acquired resistance to EGFR inhibition in EGFR-mutant lung cancers that lack the second-site EGFRT790M mutation. Cancer Discov 2: 922-933.

Tall GG, Barbieri MA, Stahl PD, Horazdovsky BF. 2001. Rasactivated endocytosis is mediated by the Rab5 guanine nucleotide exchange activity of RIN1. Dev Cell 1: 73-82.

Tanemura A, Nagasawa T, Inui S, Itami S. 2005. LRIG-1 provides a novel prognostic predictor in squamous cell carcinoma of the skin: Immunohistochemical analysis for 38 cases. Dermatol Surg 31: 423-430.

Tarcic G, Boguslavsky SK, Wakim J, Kiuchi T, Liu A, Reinitz F, Nathanson D, Takahashi T, Mischel PS, Ng T, et al. 2009. An unbiased screen identifies DEP-1 tumor suppressor as a phosphatase controlling EGFR endocytosis. Curr Biol 19: 1788-1798.

Teckchandani A, Toida N, Goodchild J, Henderson C, Watts J, Wollscheid B, Cooper JA. 2009. Quantitative proteomics identifies a Dab2/integrin module regulating cell migration. J Cell Biol 186: 99-111.

Teis D, Wunderlich W, Huber LA. 2002. Localization of the MP1-MAPK scaffold complex to endosomes is mediated by p14 and required for signal transduction. Dev Cell 3: 803-814.

Thien CB, Langdon WY. 2001. Cbl: Many adaptations to regulate protein tyrosine kinases. Nat Rev Mol Cell Biol 2: 294-307.

Thiery JP, Acloque H, Huang RY, Nieto MA. 2009. Epithelial-mesenchymal transitions in development and disease. Cell 139: 871-890.

Tomshine JC, Severson SR, Wigle DA, Sun Z, Beleford DA, Shridhar V, Horazdovsky BF. 2009. Cell proliferation and epidermal growth factor signaling in non-small cell lung adenocarcinoma cell lines are dependent on Rin1. J Biol Chem 284: 26331-26339.

Trebinska A, Rembiszewska A, Ciosek K, Ptaszynski K, Rowinski S, Kupryjanczyk J, Siedlecki JA, Grzybowska EA. 2010. HAX-1 overexpression, splicing and cellular localization in tumors. BMC Cancer 10: 76.

Tzahar E, Moyer JD, Waterman H, Barbacci EG, Bao J, Levkowitz G, Shelly M, Strano S, Pinkas-Kramarski R, Pierce $\mathrm{JH}$, et al. 1998. Pathogenic poxviruses reveal viral strategies to exploit the ErbB signaling network. EMBO J 17: 5948-5963. 
I. Mellman and Y. Yarden

van der Horst EH, Degenhardt YY, Strelow A, Slavin A, Chinn L, Orf J, Rong M, Li S, See LH, Nguyen KQ, et al. 2005. Metastatic properties and genomic amplification of the tyrosine kinase gene ACK1. Proc Natl Acad Sci 102: $15901-15906$.

Verma S, Miles D, Gianni L, Krop IE, Welslau M, Baselga J, Pegram M, Oh DY, Dieras V, Guardino E, et al. 2012. Trastuzumab emtansine for HER2-positive advanced breast cancer. $N$ Engl J Med 367: 1783-1791.

Vieira AV, Lamaze C, Schmid SL. 1996. Control of EGF receptor signaling by clathrin-mediated endocytosis. Science 274: 2086-2089.

Wang Y, Pennock S, Chen X, Wang Z. 2002. Endosomal signaling of epidermal growth factor receptor stimulates signal transduction pathways leading to cell survival. $\mathrm{Mol}$ Cell Biol 22: 7279-7290.

Wang Y, Du D, Fang L, Yang G, Zhang C, Zeng R, Ullrich A, Lottspeich F, Chen Z. 2006. Tyrosine phosphorylated Par3 regulates epithelial tight junction assembly promoted by EGFR signaling. EMBO J 25: 5058-5070.

Wang Y, Roche O, Yan MS, Finak G, Evans AJ, Metcalf JL, Hast BE, Hanna SC, Wondergem B, Furge KA, et al. 2009. Regulation of endocytosis via the oxygen-sensing pathway. Nat Med 15: 319-324.

Wang Q, Gao Y, Tang Y, Ma L, Zhao M, Wang X. 2012. Prognostic significance of RIN1 gene expression in human non-small cell lung cancer. Acta Histochem 114: 463-468.

Wiley HS. 1988. Anomalous binding of epidermal growth factor to A431 cells is due to the effect of high receptor densities and a saturable endocytic system. J Cell Biol 107: 801-810.

Wong AJ, Bigner SH, Bigner DD, Kinzler KW, Hamilton SR, Vogelstein B. 1987. Increased expression of the epidermal growth factor receptor gene in malignant gliomas is invariably associated with gene amplification. Proc Natl Acad Sci 84: 6899-6903.
Wong KK, Engelman JA, Cantley LC. 2010. Targeting the PI3K signaling pathway in cancer. Curr Opin Genet Dev 20: $87-90$.

Woods AJ, White DP, Caswell PT, Norman JC. 2004. PKD1/ PKC $\mu$ promotes $\alpha \mathrm{v} \beta 3$ integrin recycling and delivery to nascent focal adhesions. EMBO J 23: 2531-2543.

Worthylake R, Opresko LK, Wiley HS. 1999. ErbB-2 amplification inhibits down-regulation and induces constitutive activation of both ErbB-2 and epidermal growth factor receptors. J Biol Chem 274: 8865-8874.

Xu L, Lubkov V, Taylor LJ, Bar-Sagi D. 2010. Feedback regulation of Ras signaling by Rabex-5-mediated ubiquitination. Curr Biol 20: 1372-1377.

Yin YX, Shen F, Pei H, Ding Y, Zhao H, Zhao M, Chen Q. 2012. Increased expression of Rab25 in breast cancer correlates with lymphatic metastasis. Tumour Biol 33: 15811587.

Ying H, Zheng H, Scott K, Wiedemeyer R, Yan H, Lim C, Huang J, Dhakal S, Ivanova E, Xiao Y, et al. 2010. Mig-6 controls EGFR trafficking and suppresses gliomagenesis. Proc Natl Acad Sci 107: 6912-6917.

Zhang X, Pickin KA, Bose R, Jura N, Cole PA, Kuriyan J. 2007. Inhibition of the EGF receptor by binding of MIG6 to an activating kinase domain interface. Nature 450: $741-744$.

Zhang J, Liu X, Datta A, Govindarajan K, Tam WL, Han J, George J, Wong C, Ramnarayanan K, Phua TY, et al. 2009. $R C P$ is a human breast cancer-promoting gene with Ras-activating function. J Clin Invest 119: $2171-$ 2183.

Zoncu R, Bar-Peled L, Efeyan A, Wang S, Sancak Y, Sabatini DM. 2011. mTORC1 senses lysosomal amino acids through an inside-out mechanism that requires the vacuolar $\mathrm{H}^{+}$-ATPase. Science 334: 678-683.

Zwang Y, Yarden Y. 2009. Systems biology of growth factorinduced receptor endocytosis. Traffic 10: 349-363. 


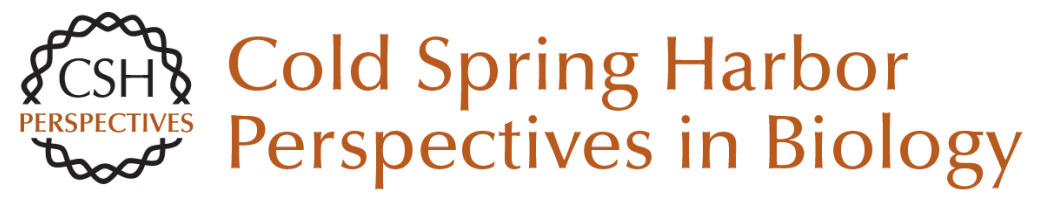

\section{Endocytosis and Cancer}

Ira Mellman and Yosef Yarden

Cold Spring Harb Perspect Biol 2013; doi: 10.1101/cshperspect.a016949

Subject Collection Endocytosis

Endocytosis: Past, Present, and Future Sandra L. Schmid, Alexander Sorkin and Marino Zerial

Rab Proteins and the Compartmentalization of the Endosomal System Angela Wandinger-Ness and Marino Zerial

Cargo Sorting in the Endocytic Pathway: A Key Regulator of Cell Polarity and Tissue Dynamics Suzanne Eaton and Fernando Martin-Belmonte

Unconventional Functions for Clathrin, ESCRTs, and Other Endocytic Regulators in the Cytoskeleton, Cell Cycle, Nucleus, and Beyond: Links to Human Disease

Frances M. Brodsky, R. Thomas Sosa, Joel A. Ybe, et al.

Endocytosis of Viruses and Bacteria Pascale Cossart and Ari Helenius

Lysosomal Adaptation: How the Lysosome

\section{Responds to External Cues} Carmine Settembre and Andrea Ballabio

Reciprocal Regulation of Endocytosis and Metabolism

Costin N. Antonescu, Timothy E. McGraw and Amira Klip

Endocytosis and Autophagy: Exploitation or Cooperation?

Sharon A. Tooze, Adi Abada and Zvulun Elazar
Imaging and Modeling the Dynamics of

Clathrin-Mediated Endocytosis

Marcel Mettlen and Gaudenz Danuser

Endocytic Accessory Factors and Regulation of

Clathrin-Mediated Endocytosis

Christien J. Merrifield and Marko Kaksonen

The Complex Ultrastructure of the Endolysosomal

System Judith Klumperman and Graça Raposo

The Biogenesis of Lysosomes and

Lysosome-Related Organelles J. Paul Luzio, Yvonne Hackmann, Nele M.G. Dieckmann, et al.

Endocytosis, Signaling, and Beyond Pier Paolo Di Fiore and Mark von Zastrow

Clathrin-Independent Pathways of Endocytosis Satyajit Mayor, Robert G. Parton and Julie G. Donaldson

The Role of Endocytosis during Morphogenetic Signaling Marcos Gonzalez-Gaitan and Frank Jülicher

Role of Endosomes and Lysosomes in Human Disease

Frederick R. Maxfield

For additional articles in this collection, see http://cshperspectives.cshlp.org/cgi/collection/

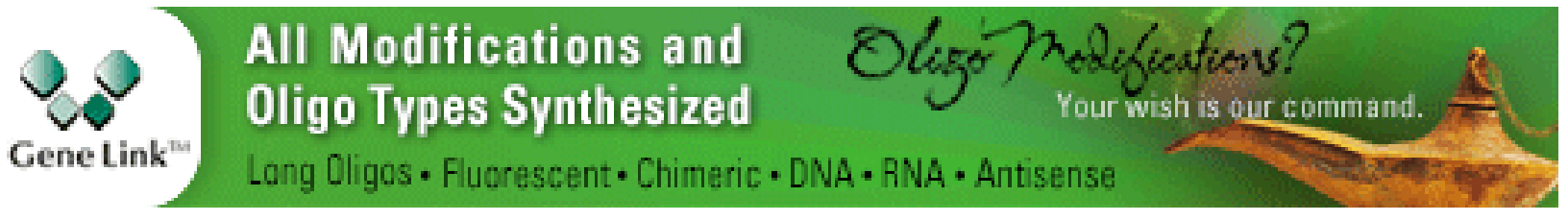


For additional articles in this collection, see http://cshperspectives.cshlp.org/cgi/collection/

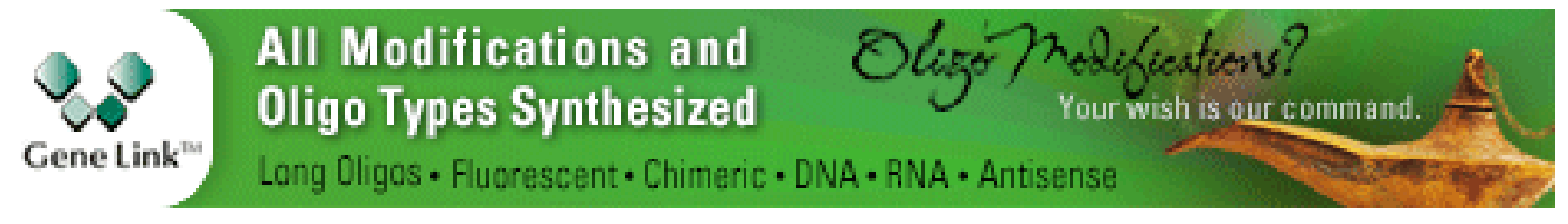

Copyright @ 2013 Cold Spring Harbor Laboratory Press; all rights reserved 